\title{
Article
}

\section{Ventilation Characteristics and Performance Evaluation of Different Window-Opening Forms in a Typical Office Room}

\author{
Yuanyuan Wang ${ }^{1}$, Yanzhe $\mathrm{Yu}^{1}{ }^{1}\left(\mathbb{D}\right.$, Tianzhen $\mathrm{Ye}^{1,2, *}$ ) and Quan Bo ${ }^{1}$ \\ 1 School of Environmental Science and Engineering, Tianjin University, Tianjin 300350, China; \\ yuanyuan16336@tju.edu.cn (Y.W.); yuyanzhe@tju.edu.cn (Y.Y.); tjboq@cohl.com (Q.B.) \\ 2 National Engineering Laboratory for Digital Construction and Evaluation Technology of Urban Rail Transit, \\ Tianjin 300350, China \\ * Correspondence: tzhye@tju.edu.cn
}

check for updates

Citation: Wang, Y.; Yu, Y.; Ye, T.; Bo, Q. Ventilation Characteristics and Performance Evaluation of Different Window-Opening Forms in a Typical Office Room. Appl. Sci. 2021, 11, 8966 https://doi.org/10.3390/ app11198966

Academic Editor: Cesare Biserni

Received: 11 September 2021 Accepted: 21 September 2021 Published: 26 September 2021

Publisher's Note: MDPI stays neutral with regard to jurisdictional claims in published maps and institutional affiliations.

Copyright: (c) 2021 by the authors. Licensee MDPI, Basel, Switzerland. This article is an open access article distributed under the terms and conditions of the Creative Commons Attribution (CC BY) license (https:// creativecommons.org/licenses/by/ $4.0 /)$.

\begin{abstract}
As most existing office buildings in China lack fresh air systems for ventilation, natural ventilation with windows remains the main means of improving indoor air quality and adjusting indoor thermal comfort. However, knowledge of the ventilation characteristics of various window-opening forms in actual buildings is limited and current methods for evaluating ventilation performance lack a comprehensive consideration of ventilation rate and thermal comfort. In this study, the ventilation characteristics of different window-opening forms were systematically compared by conducting computational fluid dynamics (CFD) simulations. A full-scale experiment was conducted in a typical office room in a university in Tianjin to validate the CFD simulation. Two ventilation modes (winddriven cross-ventilation and temperature-driven single-sided ventilation), three window-opening angles, and seven window types were investigated. Additionally, the ratio of the ventilation rate to the absolute value of thermal sensation was used to quantify the indoor natural-ventilation performance. The results showed that a sliding window with a full opening has the highest discharge coefficients of 0.68 and 0.52 under wind-driven cross-ventilation and temperature-driven single-sided ventilation, respectively, and top-hung windows opening both inwards and outwards have better ventilation performance than other window types under the two ventilation modes. This study is applicable to the design and practice of natural ventilation.
\end{abstract}

Keywords: natural ventilation; window-opening forms; ventilation performance; CFD

\section{Introduction}

Natural ventilation can help adjust indoor thermal comfort [1-3], improve indoor air quality [4,5], and reduce the energy consumption of mechanical ventilation systems [6-8]. Due to the pulsating characteristics of natural ventilation, natural ventilation can provide a comfortable indoor environment [9], which is conducive to people's physical and mental health. Thus, it is important to promote the adoption of natural ventilation in buildings.

One of the important methods of realising natural ventilation is window ventilation. The design [10-12], practice, and assessment of window ventilation [13-15] have received increasing research attention. In the design and practice of window ventilation, the window configuration, window-opening form, and opening angle are three important influencing factors [16]. Window configurations are usually categorised as cross-ventilation, where openings are on opposite sides of a building; and single-sided ventilation, where the openings are on only one side of a building [17]. There are three common window-opening forms - casement, hung, and sliding windows [18] — which can be subdivided according to the axis position and type of opening (inner and outer). Thus, various specific application forms can be obtained. The occupants usually control the window-opening angle to adjust the ventilation rate [19].

The influence of these three factors on the discharge coefficient and ventilation performance has been studied by the research community. Favarolo et al. [20] analysed the 
effects of the position of a large rectangular opening on the discharge coefficient under single-sided ventilation and concluded that the vertical position of the opening is the most important influencing factor. Heiselberg et al. [21] investigated the ventilation performance of side-hung windows and bottom-hung windows under single-sided ventilation and cross-ventilation and confirmed that the discharge coefficient varies with both the opening area and window type. Yang et al. [22] conducted computational fluid dynamics (CFD) simulations to identify a positive correlation between the discharge coefficient and the opening angles. However, the aforementioned studies are limited in terms of certain window-opening forms or window configurations. In addition, there have been few studies on the window-opening angle [23].

To evaluate the performance of natural ventilation, indices such as air change per hour [24,25] and age of air [26] are commonly used. The air change per hour is the ratio of ventilation rate per hour to room volume. The age of air refers to the time required for air from entering the room to reaching a certain point in the room, which reflects the freshness of indoor air. However, under unsteady conditions, the advantages and disadvantages of natural ventilation cannot be determined based on only the ventilation rate; the indoor thermal comfort should also be considered. For the evaluation of thermal comfort under natural ventilation, the commonly used indices are the predicted mean vote-predicted percentage dissatisfied (PMV-PPD) [27,28] and the thermal comfort adaptability model [29]. PMV represents the average cold and heat felt by most people in the same environment. PPD represents the percentage of people dissatisfied with the thermal environment. Yu et al. [30] discussed the advantages and disadvantages of the PMV and adaptive comfort models in evaluating the thermal comfort of natural ventilation and proposed that attention should be paid to their combination. In general, occupants open windows for ventilation for two main purposes: one is to meet the needs of indoor ventilation, and the other is to adjust the indoor thermal comfort. However, the current evaluation index considers only one aspect, that is, either the ventilation rate or indoor thermal comfort, and lacks a comprehensive consideration of both.

Although many studies have been conducted on the design, practice, and assessment of window ventilation, the ventilation characteristics of various window-opening forms and opening angles in actual buildings are rarely systematically and quantitatively compared. Moreover, there is a lack of comprehensive consideration of the ventilation rate and thermal comfort in the evaluation of ventilation performance. To address this research gap, in this study, natural ventilation characteristics and performance were quantified and assessed under different window-opening forms and ventilation modes. A natural ventilation experiment was conducted in an office room in a university in Tianjin to validate the CFD simulation. The natural ventilation flow under seven window types, three opening angles, and two ventilation modes was simulated by using the CFD method. The window ventilation performance was comprehensively evaluated by combining the ventilation rate and thermal comfort.

\section{Evaluation Model of Ventilation Performance}

There are two main purposes for which occupants open windows for ventilation: one is to meet the needs of indoor ventilation, and for this purpose, the greater the ventilation rate is, the better. The other purpose is to adjust the indoor thermal comfort, and for this purpose, the closer the thermal sensation of the human body to the neutral temperature is, the better. To determine thermal comfort, the modified adaptive comfort model proposed by Su [31] was used in this study to calculate the human thermal sensation neutral temperature, $t_{\mathcal{c}}$, and the expression is given as

$$
t_{c}=19.7+0.30 t_{0}+\frac{0.55 v_{\text {in }}}{0.15}
$$

where $t_{0}$ is the outdoor monthly average temperature $\left({ }^{\circ} \mathrm{C}\right)$, and $v_{\text {in }}$ is the indoor air velocity $(\mathrm{m} / \mathrm{s})$. 
The difference between the thermal neutral temperature and the actual temperature is defined as the thermal sensation (the thermal sensation here is different from the predicted average thermal sensation of the PMV-PPD method owing to the different calculation methods). To comprehensively consider the indoor ventilation rate and the thermal comfort, the ratio of the ventilation rate to the absolute value of thermal sensation can be used as an index to evaluate the natural ventilation performance: the larger the ratio is, the better the ventilation performance.

\section{Full-Scale Experiments}

\subsection{Experimental Site and Test Instruments}

The experiment was conducted in an office building in a university in Tianjin. The university is located in the suburbs, with flat and open surrounding terrain, and there are no other buildings around the experimental building. The experimental building has five floors, and the maximum number of building floors in the school is five, which reduces the influence of the complex building layout on the natural wind field. The experimental room is on the fourth floor of the office building, and the internal size of the room is $8.1 \mathrm{~m} \times 4.8 \mathrm{~m} \times 2.7 \mathrm{~m}(\mathrm{~L} \times \mathrm{W} \times \mathrm{H})$. The orientation of the north wall is $13^{\circ}$ north by east. The north wall of the office is an exterior wall having a window with two sheets, which is the casement window opening outwards. There are offices in both the east and west sides and in the floors above and below the experimental room. The south side, which has an inner door, is adjacent to the inner corridor, and the elevator hall is connected to the corridor. There is a glass window on the south side of the waiting hall, which is open and is equal to the window in the room. There are four sets of desks and chairs, and two sets of lockers in the experimental room. The dimensions of the experimental room and exterior window are shown in Figure 1, and the area and volume parameters are listed in Tables 1 and 2, respectively.

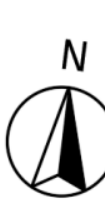

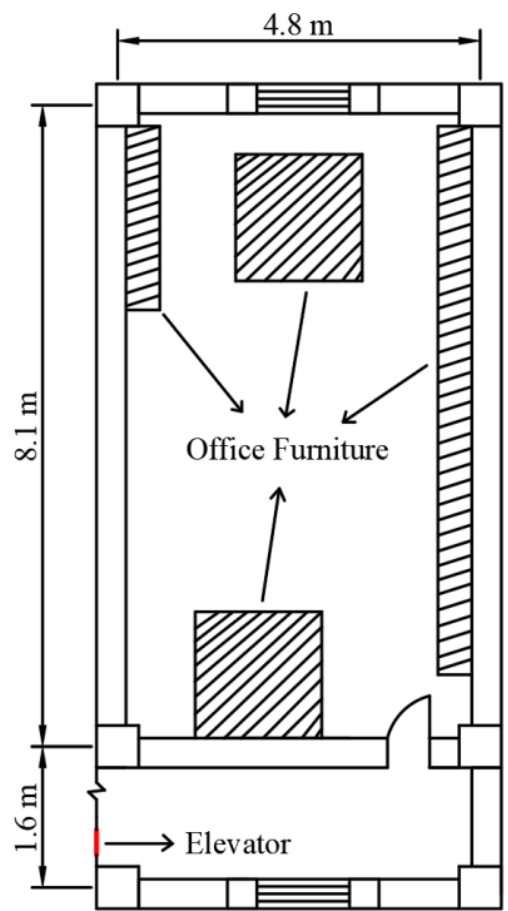

(a)

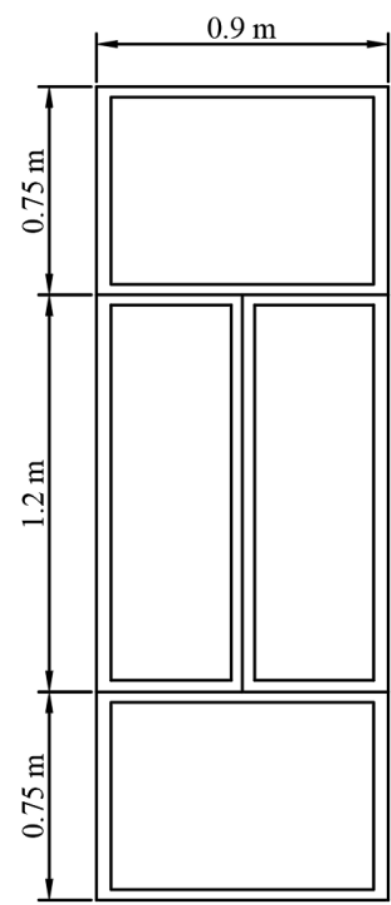

(b)

Figure 1. Dimensions of (a) experimental room and (b) exterior window. 
Table 1. Building area parameters of experimental room.

\begin{tabular}{cccccc}
\hline $\begin{array}{c}\text { Exterior Wall Area } \\
\left(\mathbf{m}^{\mathbf{2}}\right)\end{array}$ & $\begin{array}{c}\text { Exterior Window } \\
\text { Area }\left(\mathbf{m}^{\mathbf{2}}\right)\end{array}$ & $\begin{array}{c}\text { Sheet Area of the } \\
\text { Exterior Window }\left(\mathbf{m}^{\mathbf{2}}\right)\end{array}$ & $\begin{array}{c}\text { Interior Wall Area } \\
\left(\mathbf{m}^{\mathbf{2}}\right)\end{array}$ & Door Area $\left(\mathbf{m}^{\mathbf{2}}\right)$ & ${\mathbf{R o o m ~ A r e a ~}\left(\mathbf{m}^{\mathbf{2}}\right)}^{\text {Room }}$ \\
\hline 5.67 & 2.43 & 1.08 & 52.48 & 2.11 & 38.88 \\
\hline
\end{tabular}

Table 2. Building volume parameters of experimental room.

\begin{tabular}{ccc}
\hline Total Volume $\left(\mathbf{m}^{\mathbf{3}}\right)$ & Furniture Volume $\left(\mathbf{m}^{\mathbf{3}}\right)$ & Net Volume $\left(\mathbf{m}^{\mathbf{3}}\right)$ \\
\hline 104.98 & 16.64 & 88.34 \\
\hline
\end{tabular}

The indoor ventilation rate was measured using a tracer gas concentration attenuation method. $\mathrm{CO}_{2}$ was selected as the tracer gas in this experiment, and a dry ice fire extinguisher was selected to release $\mathrm{CO}_{2}$ gas. The instruments used in the test included a small weather station, temperature and humidity recorder, miniature wind pressure gauge, infrared thermometer, warm air blower, $\mathrm{CO}_{2}$ detection recorder, and carbon dioxide fire extinguisher. The instruments used are shown in Figure 2. The measuring range, resolution, accuracy, model, and supplier of the instruments are listed in Table 3.

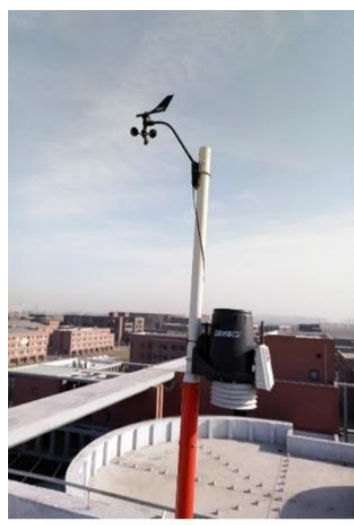

(a)

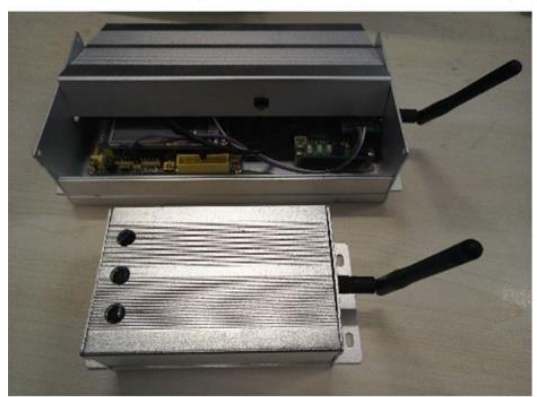

(e)

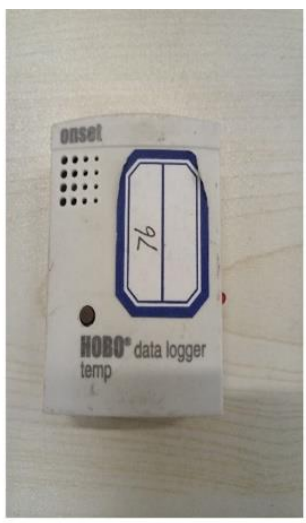

(b)

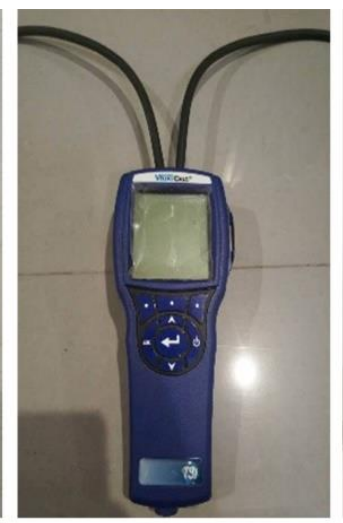

(c)

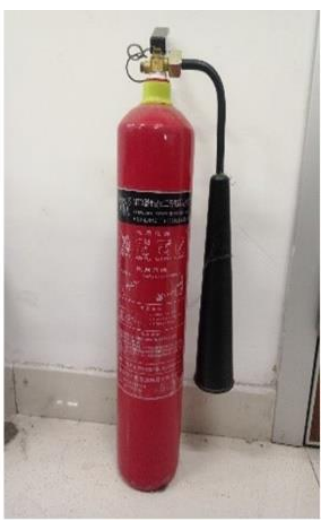

(d)

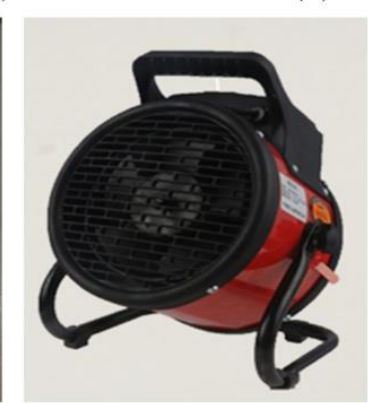

(f)

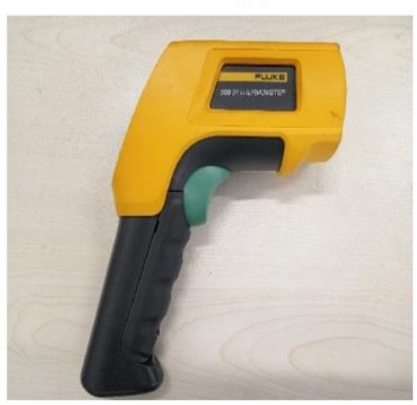

(g)

Figure 2. Experimental instruments: (a) small weather station; (b) temperature and humidity recorder; (c) miniature wind pressure gauge; (d) dry ice fire extinguisher; (e) $\mathrm{CO}_{2}$ detection recorder; (f) warm air blower; and (g) infrared thermometer.

Prior to the experiment, each instrument was calibrated to ensure test accuracy. For the small weather station installed on the experimental building roof, the installation height of the wind speed and direction sensor from the roof was at least $1.2 \mathrm{~m}$ according to the instructions. The wind vane of the wind speed and direction sensor was pointed north. The $\mathrm{CO}_{2}$ concentration sensors were placed in a well-ventilated outdoor environment without crowd interference, and the data acquisition host was connected. The sensors operated stably for more than $20 \mathrm{~min}$ at an outdoor concentration of $400 \mathrm{ppm}$, and a manual 
calibration operation was performed. The indoor temperature and humidity recorder was calibrated before leaving the factory. The miniature wind pressure gauge was placed in a windless room, and it was ensured that no person directly breathed to the instrument. The manual zero-point calibration was conducted after the wind pressure difference was stable.

Table 3. Test parameters of instruments.

\begin{tabular}{|c|c|c|c|c|c|c|}
\hline Instrument & $\begin{array}{l}\text { Parameter } \\
\text { Category }\end{array}$ & $\begin{array}{c}\text { Measuring } \\
\text { Range }\end{array}$ & Resolution & Precision & Model & Supplier \\
\hline $\begin{array}{l}\text { Small weather } \\
\text { station }\end{array}$ & $\begin{array}{c}\text { Wind speed } \\
\text { Wind direction } \\
\text { Air temperature } \\
\text { Relative humidity }\end{array}$ & $\begin{array}{c}1-68 \mathrm{~m} / \mathrm{s} \\
0^{\circ}-360^{\circ} \\
-40-65^{\circ} \mathrm{C} \\
0-100 \%\end{array}$ & $\begin{array}{c}0.1 \mathrm{~m} / \mathrm{s} \\
1^{\circ} \\
0.1^{\circ} \mathrm{C} \\
1 \%\end{array}$ & $\begin{array}{c} \pm 5 \%(1.5 \mathrm{~m} / \mathrm{s}) \\
\pm 3^{\circ} \\
\pm 0.5^{\circ} \mathrm{C} \\
\pm 3 \%\end{array}$ & Vantage pro2 & DAVIS \\
\hline $\begin{array}{l}\text { Temperature } \\
\text { and humidity } \\
\text { recorder }\end{array}$ & $\begin{array}{l}\text { Air temperature } \\
\text { Relative humidity }\end{array}$ & $\begin{array}{c}20-70{ }^{\circ} \mathrm{C} \\
25-95 \%\end{array}$ & $\begin{array}{c}0.1{ }^{\circ} \mathrm{C} \\
1 \%\end{array}$ & $\begin{array}{l} \pm 0.5{ }^{\circ} \mathrm{C} \\
\pm 3.5-5 \%\end{array}$ & U10-003 & Onset HOBO \\
\hline $\begin{array}{l}\text { Miniature wind } \\
\text { pressure gauge }\end{array}$ & Wind pressure & $-3735-+3735 \mathrm{~Pa}$ & $0.1 \mathrm{~Pa}$ & $\pm 1.5 \%$ & DP-CALC5815 & TSI \\
\hline $\begin{array}{l}\mathrm{CO}_{2} \text { detection } \\
\text { recorder }\end{array}$ & $\mathrm{CO}_{2}$ concentration & 0-5000 ppm & $1 \mathrm{ppm}$ & $\pm 50 \mathrm{ppm}$ & MH-Z14A & WINSEN \\
\hline $\begin{array}{c}\text { Infrared } \\
\text { thermometer }\end{array}$ & Wall temperature & $-40-800{ }^{\circ} \mathrm{C}$ & $0.1^{\circ} \mathrm{C}$ & $\pm 1 \%$ or $\pm 1.0^{\circ} \mathrm{C}$ & FLUKE568 & FLUKE \\
\hline
\end{tabular}

\subsection{Data Acquisition}

The sampling interval of the small weather station was set as the shortest sampling interval, i.e., $5 \mathrm{~min}$. The sampling interval of the $\mathrm{CO}_{2}$ detection recorder and the temperature and humidity recorder were set to $1 \mathrm{~min}$. The sampling interval of the miniature wind pressure gauge was set to $10 \mathrm{~s}$.

The arrangement of measurement points and instruments was as follows: the height of the outdoor temperature, wind speed, wind direction, and $\mathrm{CO}_{2}$ concentration measurement points from the ground was approximately $20 \mathrm{~m}$, and the horizontal distance to the test room was within $5 \mathrm{~m}$. For the indoor $\mathrm{CO}_{2}$ concentration measurement points, according to the provisions of the Indoor Air Quality Standard [32], 1-3 points should be set for rooms less than $50 \mathrm{~m}^{2}$. To prevent the calculation error of the ventilation rate caused by the uneven distribution of indoor $\mathrm{CO}_{2}$, the five $\mathrm{CO}_{2}$ concentration measurement points were arranged in a quincunx shape. The arrangement of the temperature and humidity measurement points was the same as that of the $\mathrm{CO}_{2}$ concentration measurement points. Based on relevant research [33], the wind pressure measurement points were symmetrically arranged, indoors and outdoors, at a distance of $30 \mathrm{~mm}$ from the window. All indoor measurement points were arranged at a height of $1.2 \mathrm{~m}$ above the ground, which is consistent with the breathing height of humans. As the warm air blower can affect the uniformity of the indoor temperature and $\mathrm{CO}_{2}$ distribution, it was placed on the south side of the room, near the interior wall. The warm air blower blows along the surface of the interior wall, thus reducing interference with the indoor air flow. Figure 3 shows the layout of the measurement points of wind-driven cross-ventilation (CV) and temperature-driven single-sided ventilation (SV). 


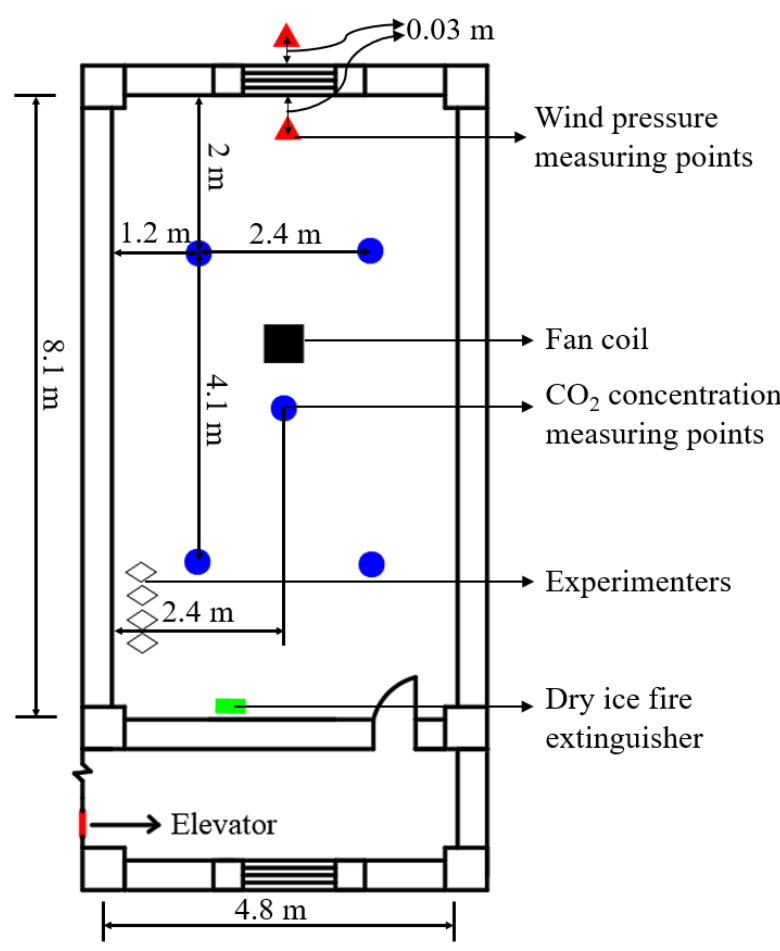

(a)

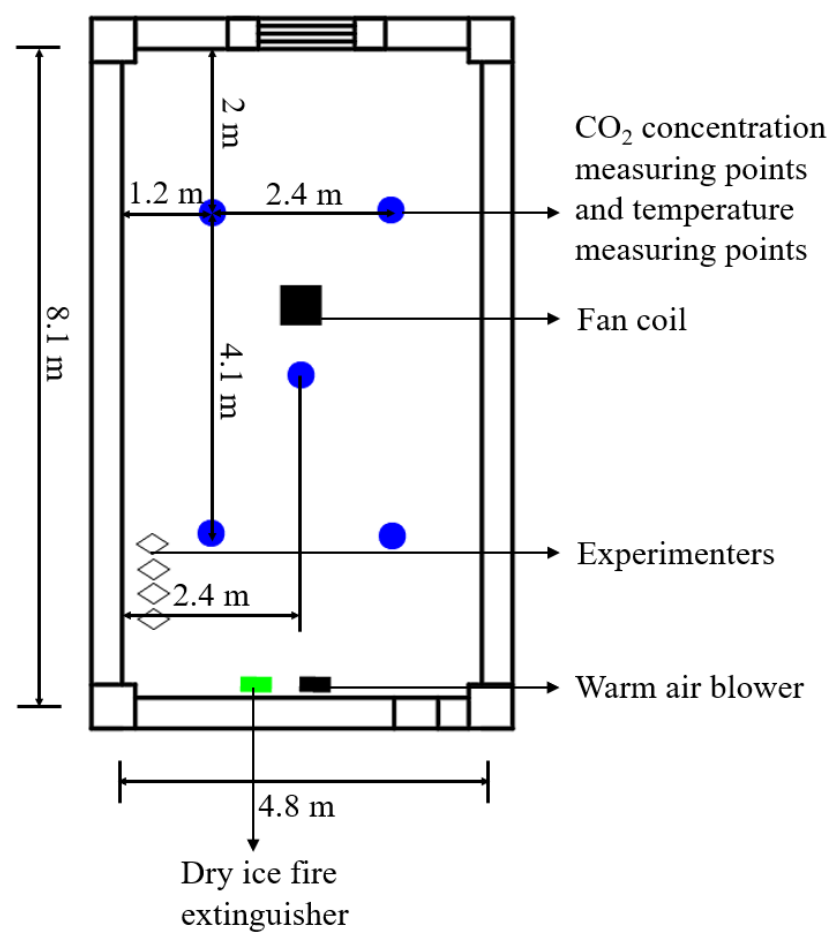

(b)

Figure 3. Layout of the measurement points of (a) CV and (b) SV.

\subsection{Experimental Conditions and Procedures}

The experiment involved two ventilation modes: $\mathrm{CV}$ and SV. For CV, the windows in the room and on the south side and the door in the room were open. For SV, only the window in the room was open. Each mode was divided into four window states according to the number of open sheets of the window and the angle of the window opening-totalling eight conditions, as listed in Table 4.

Table 4. Experimental conditions.

\begin{tabular}{ccccc}
\hline $\begin{array}{c}\text { Ventilation } \\
\text { Mode }\end{array}$ & $\begin{array}{c}\text { Condition } \\
\text { Number }\end{array}$ & Door Status & $\begin{array}{c}\text { Number of Open Sheets } \\
\text { of the Window }\end{array}$ & $\begin{array}{c}\text { Window } \\
\text { Opening }\end{array}$ \\
\hline & $1-1$ & & 1 & $30^{\circ}$ \\
CV & $1-2$ & Open & 2 & $30^{\circ}$ \\
& $1-3$ & & 1 & $45^{\circ}$ \\
& $1-4$ & & 2 & $45^{\circ}$ \\
\hline & $2-1$ & & 1 & $30^{\circ}$ \\
SV & $2-2$ & Closed & 1 & $30^{\circ}$ \\
& $2-3$ & & 2 & $45^{\circ}$ \\
\hline
\end{tabular}

Before each experiment, to eliminate the influence of $\mathrm{CO}_{2}$ produced by the experimenters' respiration on the measurement of tracer gas concentration, the rate of the $\mathrm{CO}_{2}$ production of the experimenters was measured. There were four experimenters in the room. The experimental procedures were as follows: all gaps except the door and window were well sealed. A dry ice fire extinguisher was used to spray $\mathrm{CO}_{2}$ into the test room. The initial concentration was not significantly high or low; an excessively high concentration can harm the health of the experimenters, whereas if it is too low, it can affect test accuracy. According to the literature [34], 1800 ppm was set as the lower limit of the initial concentration of $\mathrm{CO}_{2}$. For the upper limit, when the $\mathrm{CO}_{2}$ concentration in the air is 2000-4000 ppm, 


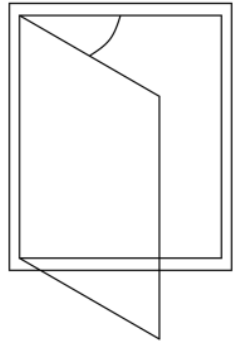

(a)

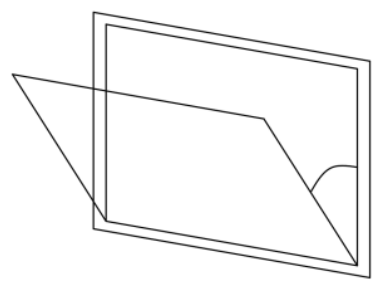

(e)

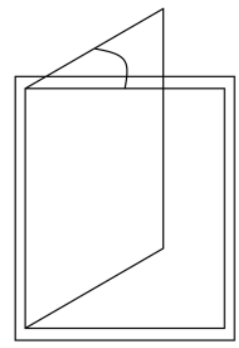

(b)

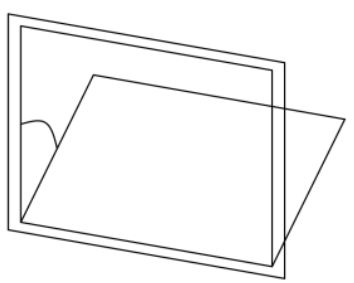

(f)

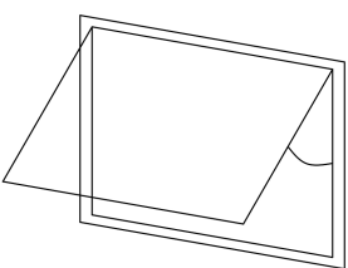

(c)

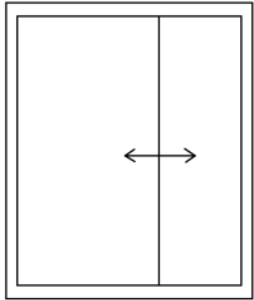

$(\mathrm{g})$

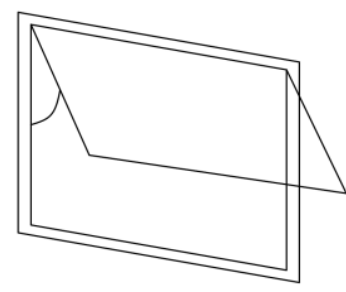

(d)

Figure 4. Diagrams of the seven windows: (a) CWI; (b) CWO; (c) THWI; (d) THWO; (e) BHWI; (f) BHWO; and (g) SW.

At present, room models established by researchers in CFD simulations of natural ventilation are mostly classified into two types: the single-opening model and the doubleopening model with windows on opposite walls. The first model is suitable for SV in this study, whereas the latter model is relatively rare in actual buildings. When the influence of wind direction on natural ventilation is considered, the windward and leeward sides cannot be distinguished because of the geometric symmetry. Therefore, a room model with a corridor was proposed for $\mathrm{CV}$ in this study. The layout of the model room was the same as that of the experimental room. As the wall thickness had a minor effect on the discharge coefficient of windows [20], and when the upper, lower, left, and right adjacent rooms open the windows, it has little impact on the indoor ventilation [36]. Therefore, according to the above similar studies, the wall thickness and adjacent rooms were not considered in the CFD models. The model conforms to a common office structure. It can distinguish the windward and leeward sides, and it avoids setting a complex model, which simplifies 
the simulation process. Figure 5 shows the models of the two ventilation modes. The size of the model room is $8.1 \mathrm{~m} \times 4.8 \mathrm{~m} \times 2.7 \mathrm{~m}(\mathrm{~L} \times \mathrm{W} \times \mathrm{H})$. The window-opening size of the room is $0.45 \mathrm{~m} \times 1.18 \mathrm{~m}(\mathrm{~W} \times \mathrm{H})$. In the $\mathrm{CV}$ model, the corridor size is $4.8 \mathrm{~m} \times 1.6 \mathrm{~m}$ $(\mathrm{L} \times \mathrm{W})$, the window-opening size of the corridor is the same as that of the room, and the door size is $0.9 \mathrm{~m} \times 2.34 \mathrm{~m}(\mathrm{~W} \times \mathrm{H})$. The outfield area was set outside the room. Referring to the relevant research [37], the distances from the left, right, front, rear, and top sides of the outfield to the corresponding surfaces of the room model were set as $6 \mathrm{H}, 6 \mathrm{H}, 3 \mathrm{H}, 3 \mathrm{H}$, and $3 \mathrm{H}$, respectively ( $\mathrm{H}$ is the height of the model room).
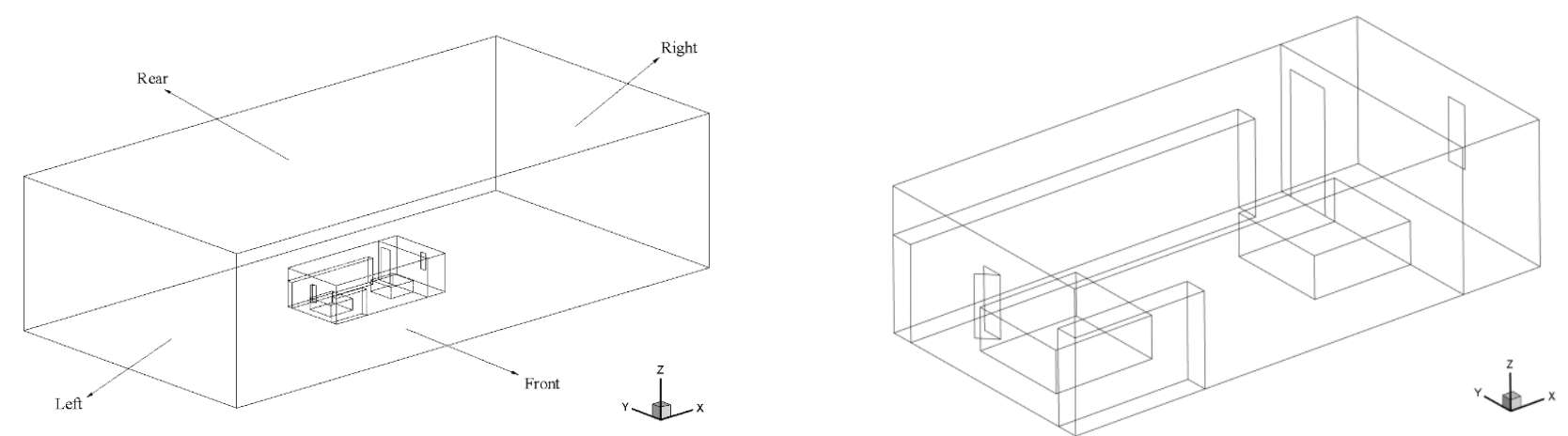

(a)
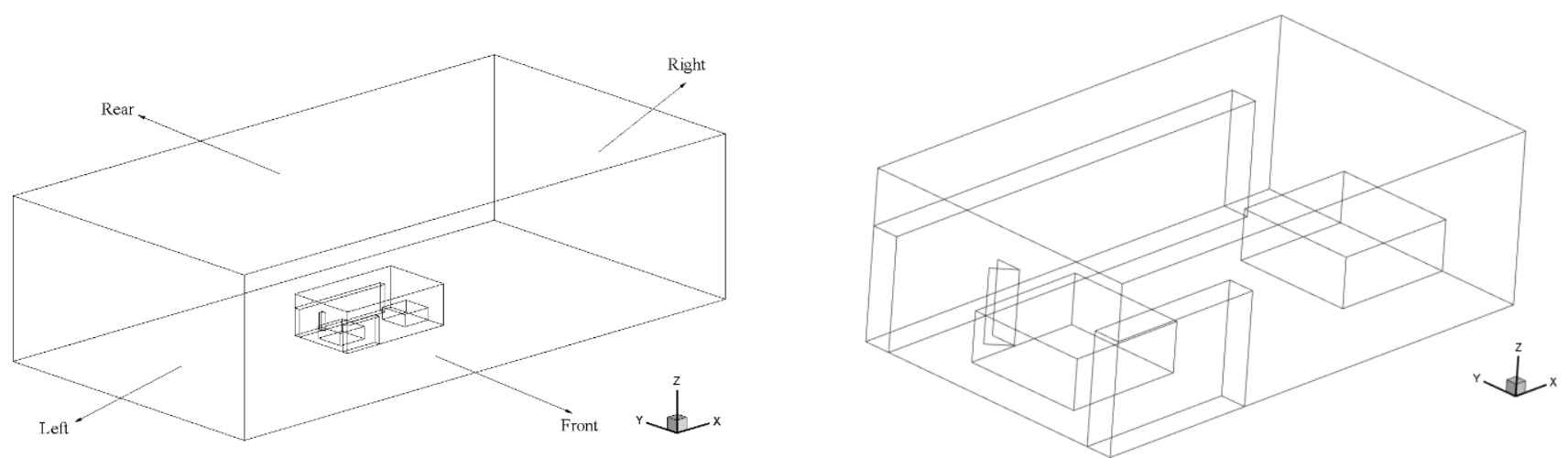

(b)

Figure 5. Geometric models: (a) CV and (b) SV.

In this study, an industry-leading fluid simulation software, ANSYS Fluent [38], was used, which can accurately solve the widest range of CFD problems. Three-dimensional steady-state Reynolds-averaged Navier-Stokes models [39] were used because of their low requirements for computer memory space and computing speed. As the natural ventilation problem in this study belonged to a flow with a high Reynolds number and high shear rate, it was suitable to adopt the realisable $\mathrm{k}-\varepsilon$ turbulence model $[40,41]$. A pressure-based solver, which is applicable to the low-speed incompressible flow problem in this study and has a fast convergence speed, was adopted, and the SIMPLE algorithm was employed for the coupling of the pressure and velocity fields.

\subsection{Numerical Grids and Boundary Conditions}

A hybrid grid was established, including a tetrahedral unstructured mesh between the model room and outfield boundary and a hexahedral structured grid inside the model room. To ensure the accuracy of the numerical simulation and simplify the complexity of the simulation calculation, the grid spacing in the model room was $0.1 \mathrm{~m}$, and the grid spacing from the model room to the outfield changed from $0.1 \mathrm{~m}$ to $1 \mathrm{~m}$ at a rate of 1.1 . As the high Reynolds number $k-\varepsilon$ model and standard wall function method were used in 
this study, the grid near the wall was not encrypted, but the first node was arranged in the region where turbulence was fully developed [38]. The total numbers of cells in the CV and SV grids were approximately 1,910,000 and 1,610,000, respectively. A grid independence analysis was carried out by increasing the numbers of cells to 4.77 million and 4.01 million for the CV and SV grids when the window is the CWO, respectively. Simulation results based on the two numbers of cells in the grids showed that there were negligible differences in the ventilation rate, confirming that the grid independence test was satisfactory.

The boundary conditions are shown in Figure 6. For the CV model, the velocity-inlet boundary condition was applied to the inlet surface of the outfield. The velocity of the outfield was fixed at $2.2 \mathrm{~m} / \mathrm{s}$ according to the average wind speed in the transition season in Tianjin. The outflow boundary condition was applied to the outlet surface of the outfield. A symmetrical boundary condition was applied to the sides and top of the outfield. The bottom of the outfield and the wall of the room were set as the wall boundary condition. For the SV model, the boundary conditions of the outlet surface, sides, and top of the outfield were the same as those of the CV model. The bottom of the outfield and the wall and floor of the room were assigned a wall boundary condition with a fixed temperature. The velocity of the outfield was set to be $0.1 \mathrm{~m} / \mathrm{s}$ to form a flow and realise the ventilation process. In the simulation validation, the measured value of the average outdoor air temperature was taken as the outfield inflow temperature boundary condition, and the measured values of the wall temperature of the room under different conditions were taken as the wall temperature boundary condition. According to the relevant research, when the outdoor air temperature was higher than $10^{\circ} \mathrm{C}$ and the indoor temperature was higher than $22{ }^{\circ} \mathrm{C}$, the window opening probability of occupants began to increase significantly [42]. Therefore, in further simulations, the temperature of the outfield inflow and the bottom of outfield was set to $10{ }^{\circ} \mathrm{C}$, and the wall and floor temperatures of the room were set to $22{ }^{\circ} \mathrm{C}$. For the velocity-inlet boundary condition, the method of turbulent intensity and viscosity ratio was specified. The turbulent intensity was $5 \%$, and the turbulent viscosity ratio was 10 .

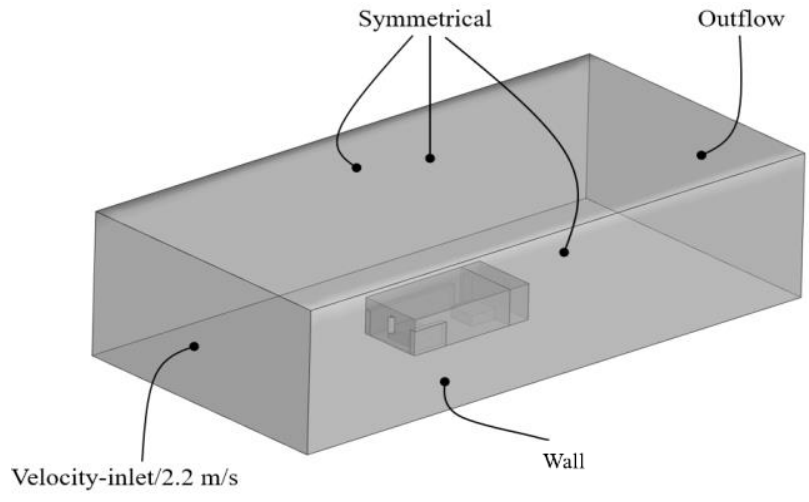

(a)

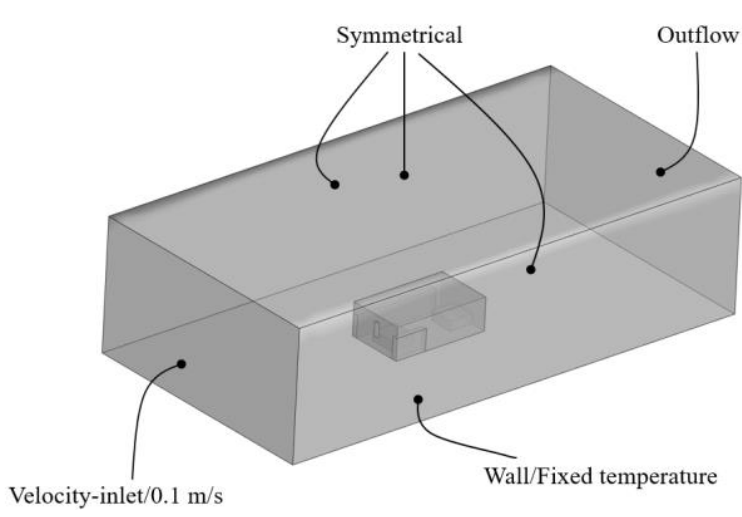

(b)

Figure 6. Boundary conditions: (a) CV and (b) SV.

\subsection{CFD Validation}

\subsubsection{Validation of Wind Pressure Difference and Discharge Coefficient for CV Model}

Owing to the limitation of the indoor $\mathrm{CO}_{2}$ release concentration, the duration of the $\mathrm{CO}_{2}$ attenuation process needed to calculate the ventilation rate in the experiment is short; therefore, for the validation of the discharge coefficient, the simulated values can be directly compared with the measured value. However, the validation of the wind pressure coefficient $\left(C_{p}\right)$ was different. First, the measurement of the wind pressure difference does not depend on the tracer gas method, and it can be carried out independently. Second, the instrument measurement interval of the wind pressure difference can be smaller than that of the outdoor wind speed and direction. Therefore, the method of the combination 
of mean comparison and sequence correlation comparison was used to validate the wind pressure difference.

In the process of the wind pressure difference test, 50 min was taken as the length of each sequence, and 10 sequences were compared. The time interval of the simulated values in each sequence was $5 \mathrm{~min}$, with a total of 10 values, and the time interval of the measured values was $10 \mathrm{~s}$, with a total of 300 values. The mean values and Pearson correlation coefficients between the simulated value sequence and the measured value sequence are listed in Table 5, in which the minimum correlation coefficient is 0.746 .

Table 5. Comparison of mean values and Pearson correlation coefficients of wind pressure difference.

\begin{tabular}{cccccc}
\hline \multirow{2}{*}{$\begin{array}{c}\text { Serial } \\
\text { Number }\end{array}$} & $\begin{array}{c}\text { Mean Wind } \\
\text { Speed (m/s) }\end{array}$ & $\begin{array}{c}\text { Dominant Wind } \\
\text { Direction }\end{array}$ & $\begin{array}{c}\text { Simulated Value } \\
\mathbf{( P a )}\end{array}$ & $\begin{array}{c}\text { Measured Value } \\
\mathbf{( P a )}\end{array}$ & $\begin{array}{c}\text { Pearson Correlation } \\
\text { Coefficient }\end{array}$ \\
\hline 1 & 4.0 & $67.5^{\circ}$ & 2.53 & 2.19 & 0.868 \\
2 & 2.2 & $315^{\circ}$ & 1.20 & 1.55 & 0.746 \\
3 & 2.5 & $112.5^{\circ}$ & 0.51 & 0.40 & 0.774 \\
4 & 2.1 & $112.5^{\circ}$ & 0.38 & 0.33 & 0.769 \\
5 & 3.3 & $67.5^{\circ}$ & 0.58 & 0.46 & 0.832 \\
6 & 1.2 & $45^{\circ}$ & 1.12 & 1.40 & 0.809 \\
7 & 1.7 & $247.5^{\circ}$ & 0.47 & 0.31 & 0.798 \\
8 & 2.4 & $270^{\circ}$ & 0.32 & 0.41 & 0.755 \\
9 & 3.8 & $225^{\circ}$ & 1.91 & 2.26 & 0.817 \\
10 & 2.1 & $112.5^{\circ}$ & 0.38 & 0.33 & 0.769 \\
\hline
\end{tabular}

A comparison between the CFD simulation values and experimental values of the discharge coefficient for $\mathrm{CV}\left(C_{d}\right)$ is presented in Table 6.

Table 6. Comparison between simulated and experimental values of the discharge coefficient under CV.

\begin{tabular}{ccccccc}
\hline $\begin{array}{c}\text { Condition } \\
\text { Number }\end{array}$ & $\begin{array}{c}\text { Outdoor Mean } \\
\text { Wind Speed } \\
(\mathbf{m} / \mathbf{s})\end{array}$ & $\begin{array}{c}\text { Dominant } \\
\text { Wind } \\
\text { Direction }\end{array}$ & $\begin{array}{c}\text { Average Temperature } \\
\text { Difference between } \\
\text { Indoor and Outdoor }\left({ }^{\circ} \mathbf{C}\right)\end{array}$ & $\begin{array}{c}\text { Simulated } \\
\text { Value }\end{array}$ & $\begin{array}{c}\text { Experimental } \\
\text { Value }\end{array}$ & $\begin{array}{c}\text { Relative } \\
\text { Error }\end{array}$ \\
\hline $1-1$ & 0.2 & $112.5^{\circ}$ & 3.9 & 0.319 & 0.335 \\
$1-2$ & 3.0 & $22.5^{\circ}$ & 3.3 & 0.457 & 0.474 & $3.8 \%$ \\
$1-3$ & 3.0 & $202.5^{\circ}$ & 1.1 & 0.413 & 0.404 & $-2.2 \%$ \\
$1-4$ & 2.6 & $337.5^{\circ}$ & 1.4 & 0.270 & 0.261 & $-3.4 \%$ \\
\hline
\end{tabular}

\subsubsection{Validation of the Discharge Coefficient for SV Model}

A comparison between the CFD simulation values and the experimental values of the discharge coefficient for SV $\left(C_{d}^{\prime}\right)$ is presented in Table 7.

Table 7. Comparison between simulated and experimental values of the discharge coefficient under SV.

\begin{tabular}{|c|c|c|c|c|c|c|c|}
\hline \multirow{2}{*}{$\begin{array}{l}\text { Condition } \\
\text { Number }\end{array}$} & \multirow{2}{*}{$\begin{array}{l}\text { Outdoor Mean } \\
\text { Wind Speed } \\
(\mathrm{m} / \mathrm{s})\end{array}$} & \multicolumn{3}{|c|}{$\begin{array}{c}\text { Indoor and Outdoor Average Temperature } \\
\text { Difference }\end{array}$} & \multicolumn{3}{|c|}{$C_{d}{ }^{\prime}$} \\
\hline & & $\begin{array}{l}\text { Simulated } \\
\text { Value }\end{array}$ & $\begin{array}{l}\text { Experimental } \\
\text { Value }\end{array}$ & $\begin{array}{l}\text { Relative } \\
\text { Error }\end{array}$ & $\begin{array}{l}\text { Simulated } \\
\text { Value }\end{array}$ & $\begin{array}{l}\text { Experimental } \\
\text { Value }\end{array}$ & $\begin{array}{l}\text { Relative } \\
\text { Error }\end{array}$ \\
\hline $2-1$ & 2.0 & 15.5 & 16.6 & $6.6 \%$ & 0.360 & 0.371 & $3.0 \%$ \\
\hline $2-2$ & 1.2 & 17.5 & 18.7 & $6.4 \%$ & 0.363 & 0.356 & $-2.0 \%$ \\
\hline $2-3$ & 1.0 & 18.3 & 19.8 & $7.6 \%$ & 0.408 & 0.395 & $-3.3 \%$ \\
\hline $2-4$ & 1.2 & 8.3 & 9.0 & $7.8 \%$ & 0.426 & 0.430 & $0.9 \%$ \\
\hline
\end{tabular}


From Tables 6 and 7, it can be observed that the agreement between the CFD results and the experimental data is acceptable, and the CFD model can be used for subsequent simulations.

\section{Results and Discussion}

\subsection{Comparison of Ventilation Characteristics of Seven Window Types with Different Wind Directions under $C V$}

In $\mathrm{CV}$, the window-opening angle was $30^{\circ}$, and the window-opening area was equal. The simulated conditions of $\mathrm{CV}$ were divided according to the angle between the incoming wind direction and the plane of the window based on the 16-wind direction interval method, where $0^{\circ}\left(360^{\circ}\right)$ was condition 1 , each increase of $22.5^{\circ}$ was a condition, and $337.5^{\circ}$ was condition 16 . According to the left and right symmetry, the seven window types were divided into two types: symmetrical windows, namely THWI, THWO, BHWI, $\mathrm{BHWO}$, and SW, and asymmetric windows, namely CWI and CWO. Figure 7 depicts the simulated wind pressure and discharge coefficients for different window types in different wind directions.
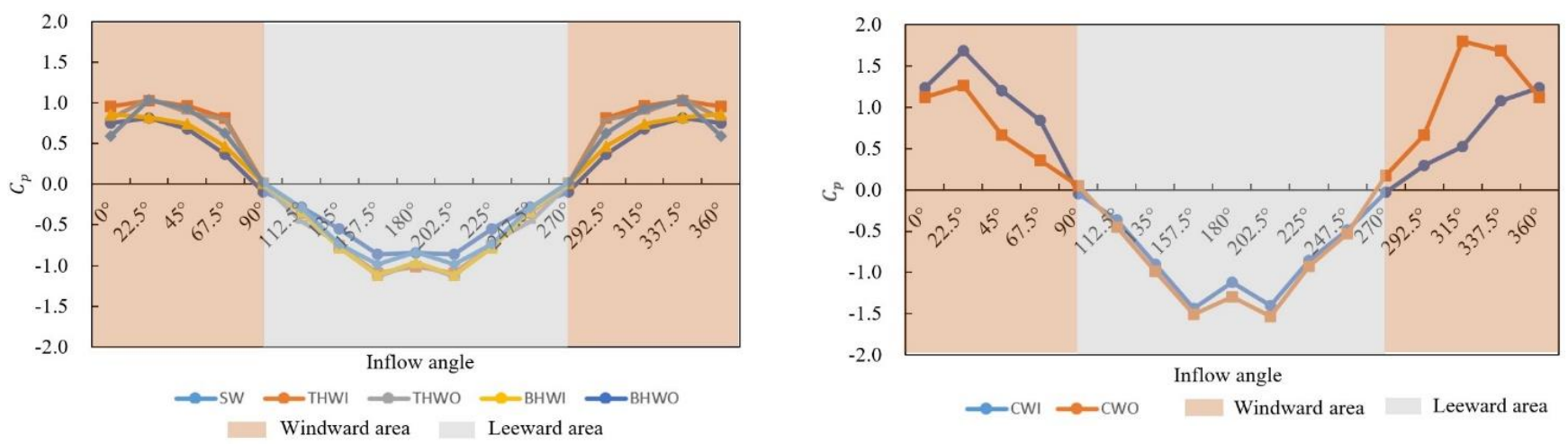

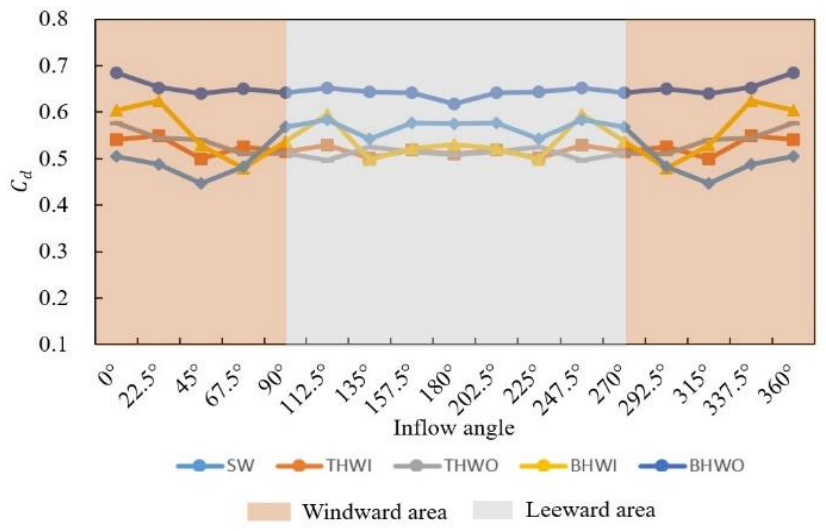

(a)

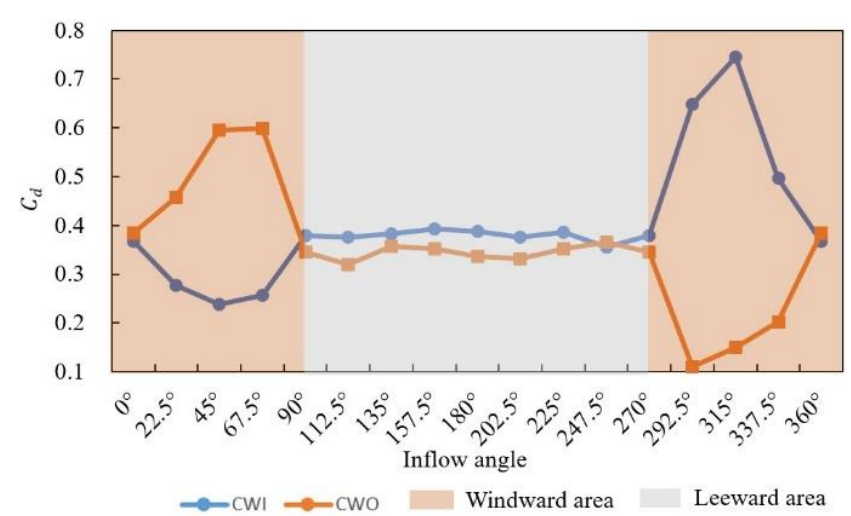

(b)

Figure 7. $C_{p}$ and $C_{d}$ of the (a) symmetrical window and (b) asymmetrical window.

As shown in Figure 7, the overall changing trend of the wind pressure coefficient of the symmetrical windows is similar. It is worth noting that on the windward side, the maximum value of the wind pressure coefficient does not appear at $0^{\circ}\left(360^{\circ}\right)$, but under the symmetrical condition of $22.5^{\circ}\left(337.5^{\circ}\right)$; there is a similar situation on the leeward side, where the minimum value of the coefficient appears in the symmetrical conditions of $157.5^{\circ}\left(202.5^{\circ}\right)$. For the asymmetrical window, the wind pressure coefficient is higher on one side for the left and right directions of the windward window, and the high and low directions of the CWI and CWO are opposite, and the trend is similar on the leeward side. The maximum and minimum values of the wind pressure coefficient still deviate from $0^{\circ}\left(360^{\circ}\right)$ and $180^{\circ}$. The discharge coefficient of symmetrical windows fluctuates in a 
small range under different wind directions, and there is no obvious distinction between the windward and leeward sides. The discharge coefficient of the asymmetric window fluctuates considerably on the windward side and gently on the leeward side.

5.2. Comparison of Ventilation Characteristics of Seven Window Types with Three Opening Angles under $C V$ and $S V$

In CV, the wind direction was fixed to the plane of the window. Three opening angles of each window type were simulated, in which the window opening state of the sliding window was set as one-third, two-thirds, and fully open, and the window-opening states of other window types were set as $15^{\circ}, 30^{\circ}$, and $45^{\circ}$, respectively. The three types of openings were defined as small, medium, and large openings, respectively.

The discharge coefficients of the three opening angles for the seven window types under the two ventilation modes were simulated, as shown in Figure 8. The discharge coefficient for each window type under $\mathrm{CV}$ is generally larger than that under SV, and the difference in discharge coefficient of each window type of the three openings under SV is less obvious than that under $\mathrm{CV}$, which is due to the different mechanisms of wind pressure ventilation and thermal pressure ventilation, resulting in different airflow characteristics at the openings. In addition, for CV and SV, the discharge coefficient increases with the increase in window opening, and the SW has the highest discharge coefficient under a large opening, which is 0.68 , and 0.52 , respectively. For medium and small openings, the discharge coefficient of BHWI is the highest under $\mathrm{CV}$, and the discharge coefficient of THWI is the highest under SV.

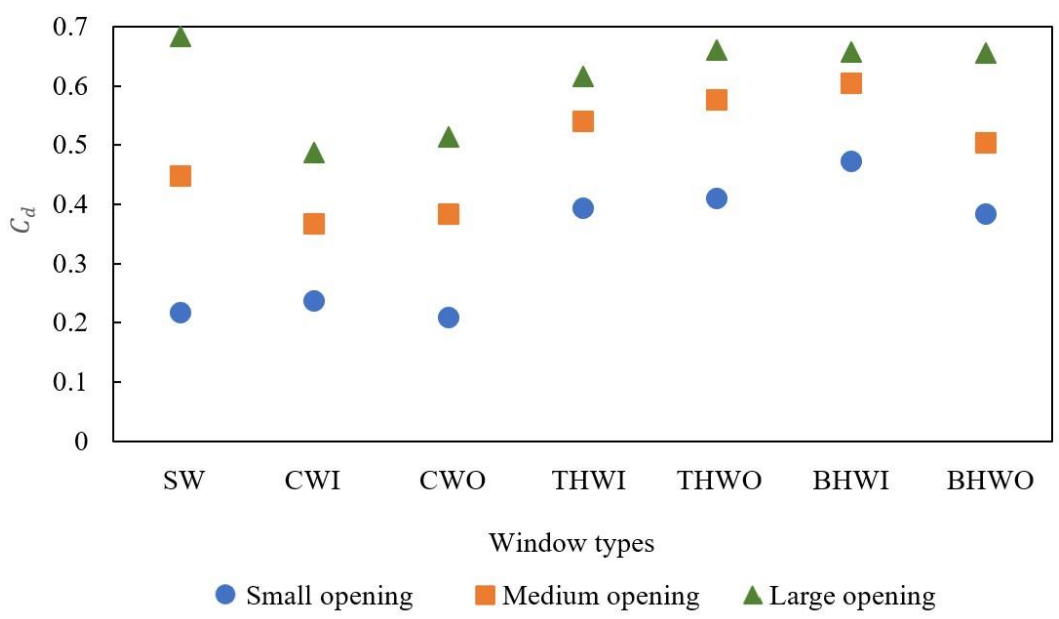

(a)

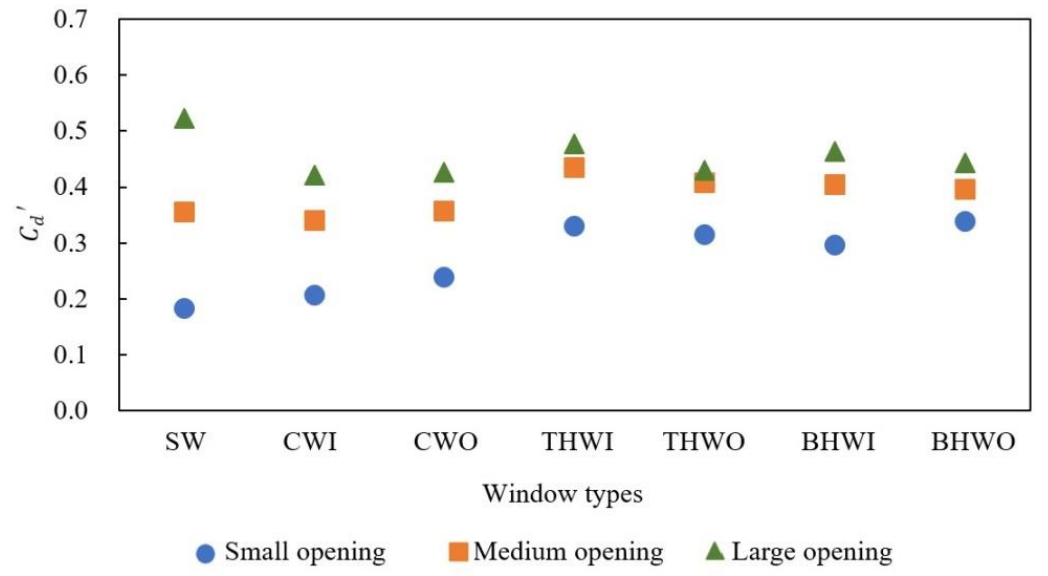

(b)

Figure 8. $C_{d}{ }^{\prime}$ of three openings for seven window types: (a) CV and (b) SV. 


\subsection{Comprehensive Evaluation of Ventilation Performance of Different Window Types}

According to the description of the temperature and wind sensitive area of ANSI/ ASHRAE Standard 55-2013, a $1.1 \mathrm{~m}$ height plane (head height of a human when sitting) in the room was selected for ventilation comfort analysis [43]. Figure 9 shows the velocity field and velocity vector of each window under the two ventilation modes. In the plan of the room, the exterior window of the room is located on the left. For $\mathrm{CV}$, the influence range of the airflow is small under the three opening angles for CWO and BHWI, whereas the influence range for SW, THWI, and BHWO is large. The airflow influence range for CWI and THWO is small only under a small opening.

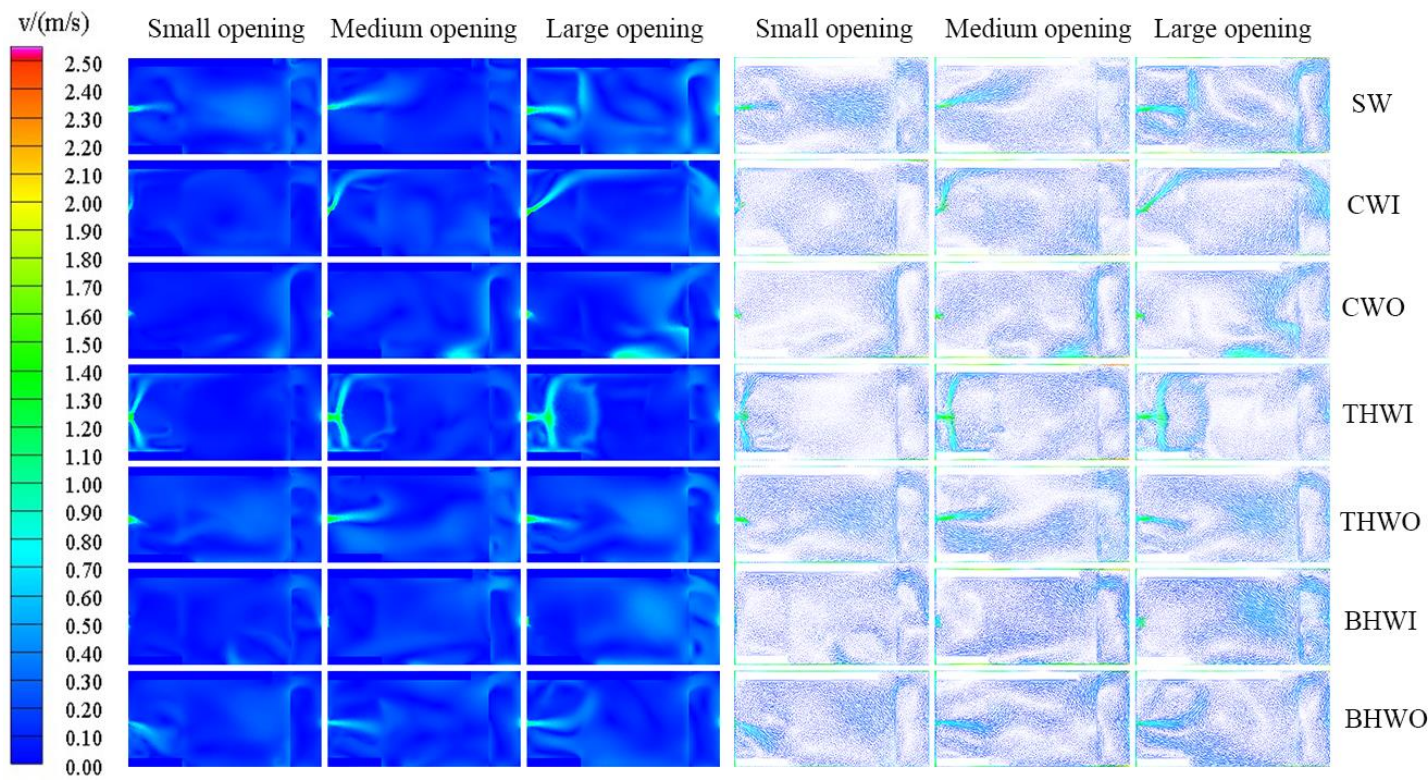

(a)

Small opening Medium opening Large opening Small opening Medium opening Large opening
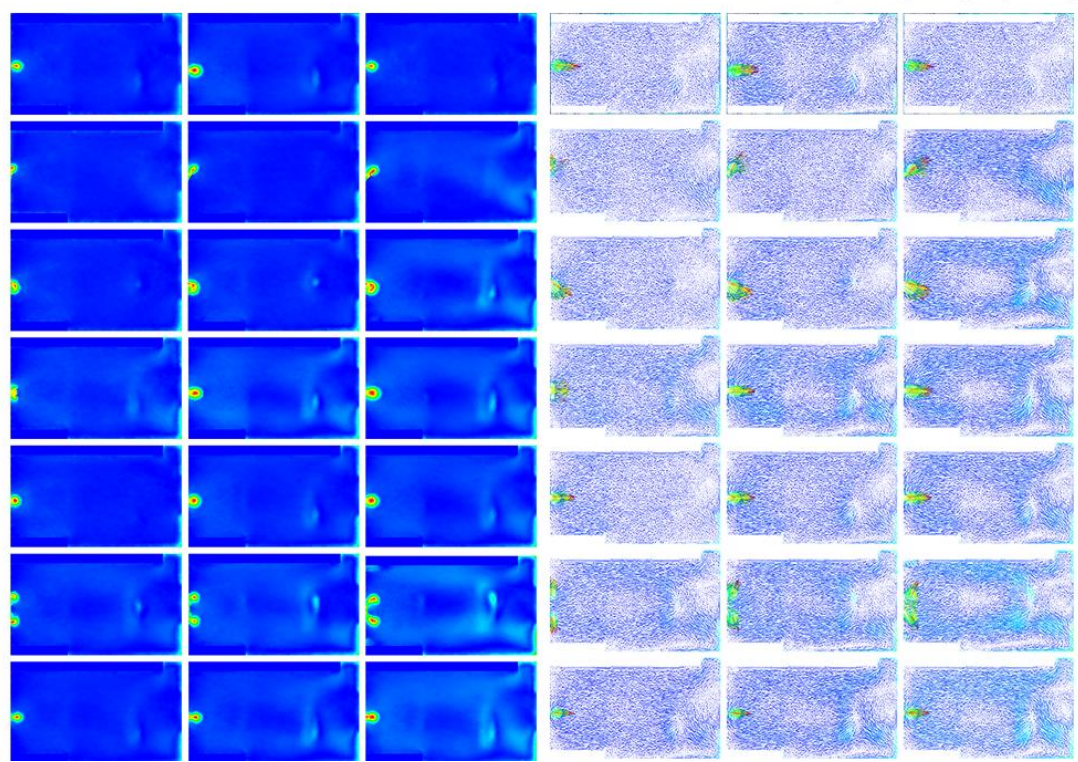

SW

CWI

CWO
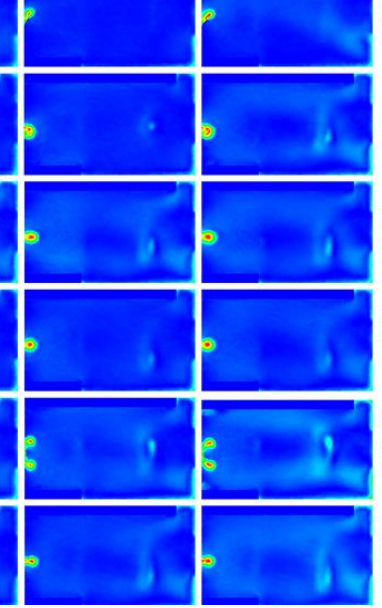

(b)

Figure 9. Velocity field and velocity vector diagram of seven window types under (a) CV and (b) SV.

Furthermore, the neutral temperature, average thermal sensation, and the proportion of thermal sensation interval of different window-opening forms of the $\mathrm{z}=1.1 \mathrm{~m}$ plane of the room were calculated according to the method described in Section 3.3. For CV, 
the outdoor temperature was set to $25{ }^{\circ} \mathrm{C}$ according to the outdoor monthly average temperature during the experiment. For SV, the outdoor temperature was $10^{\circ} \mathrm{C}$, the same as that set in the simulation process. The average thermal sensation and proportion of thermal sensation intervals under the three opening angles of the two ventilation modes are shown in Figure 10.

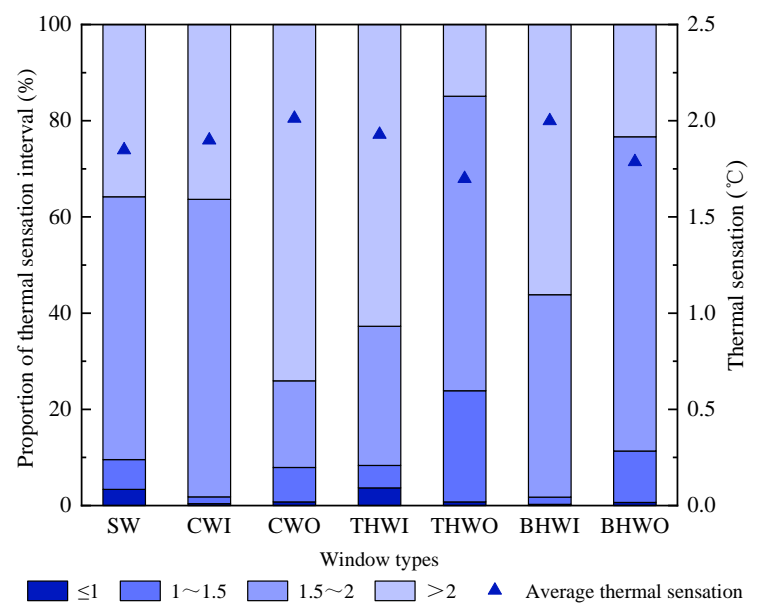

(a)

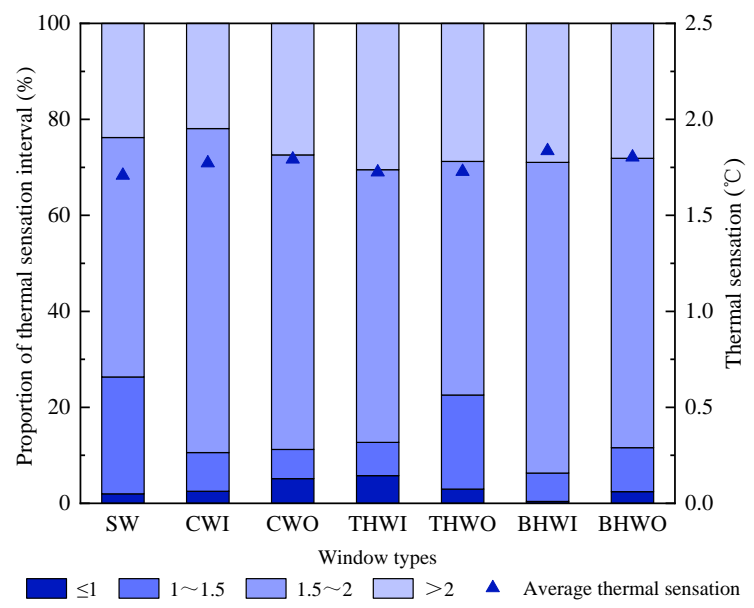

(b)

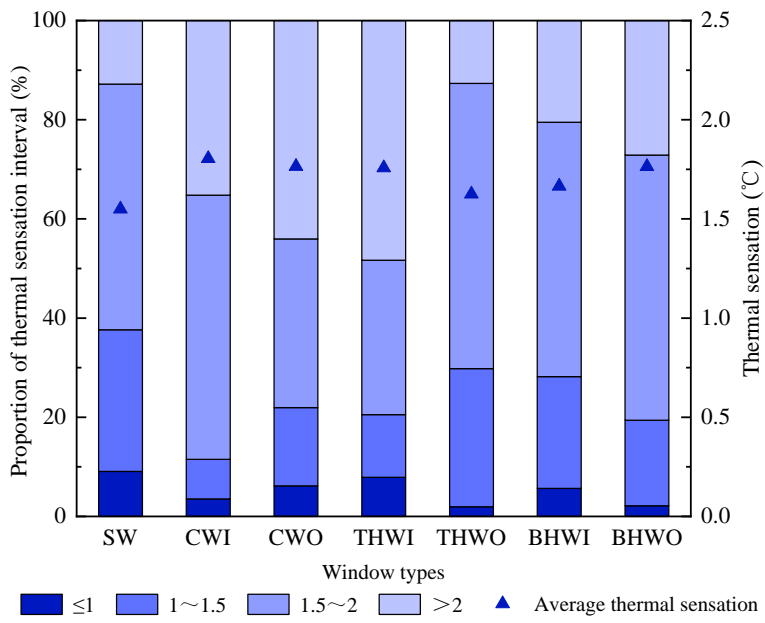

(c)

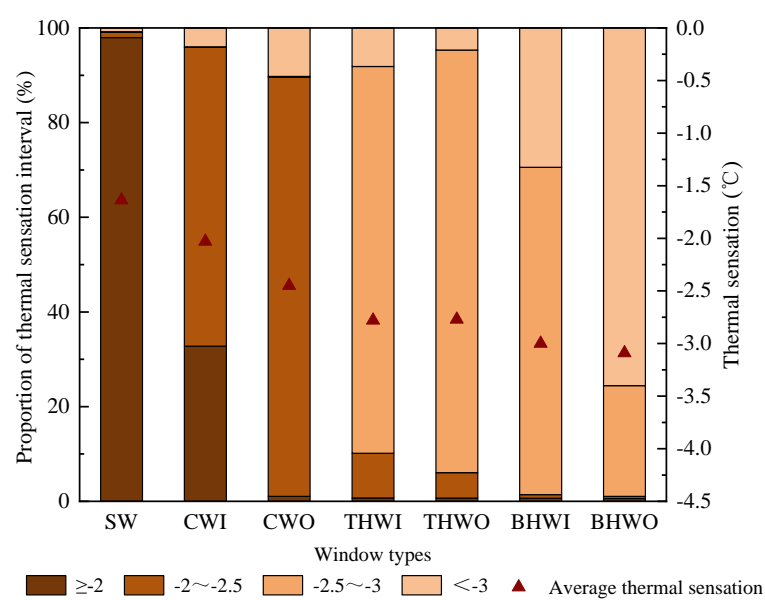

(d)

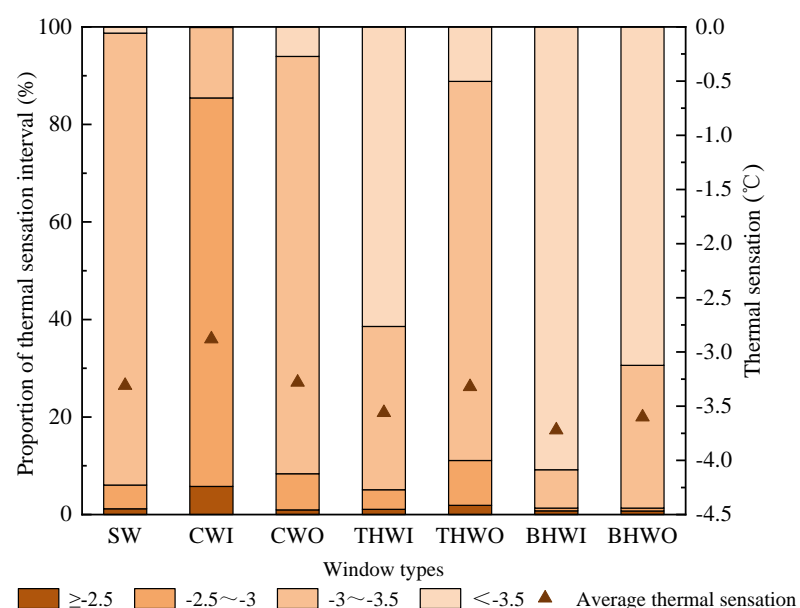

(e)

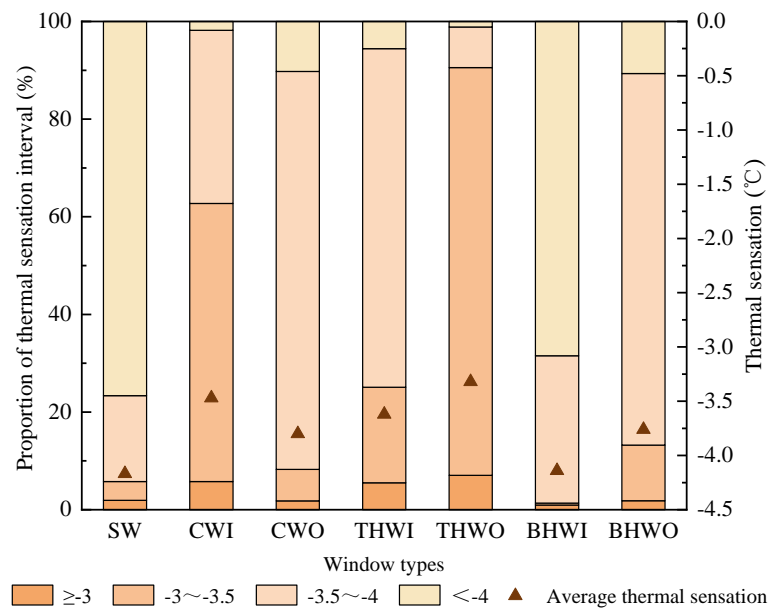

(f)

Figure 10. Average thermal sensation and proportion of thermal sensation interval: (a) small opening for $\mathrm{CV}$; (b) medium opening for $\mathrm{CV}$; (c) large opening for CV; (d) small opening for SV; (e) medium opening for SV; and (f) large opening for SV. 
It can be observed that, for $\mathrm{CV}$, the average thermal sensation of the seven window types is within the comfort zone under the three opening degrees. The comfort of the THWO is the best under a small opening, and the comfort of the seven window types is similar under the medium opening. The comfort of the SW is the best under a large opening. For SV, the average thermal sensation of the seven window types is beyond the range of the thermal comfort zone under medium opening and large opening. The comfort of the SW is best under a small opening.

To evaluate the ventilation performance of the different window-opening forms comprehensively, the ventilation rate for $C V(Q)$ and $S V\left(Q^{\prime}\right)$ of each window type was obtained by CFD simulation. Figure 11 presents a comprehensive comparison of the ventilation rate and thermal comfort of the $\mathrm{z}=1.1 \mathrm{~m}$ plane under different conditions. As can be observed from Figure 11, SW-1 (the full opening of the sliding window) has the maximum ventilation rate under the two ventilation modes. The thermal sensations of the two ventilation modes are not close to 0 or equal to 0 . The thermal sensations of the seven window types are similar under $\mathrm{CV}$, and the thermal sensations of windows with large openings are worse than those with small openings under SV.

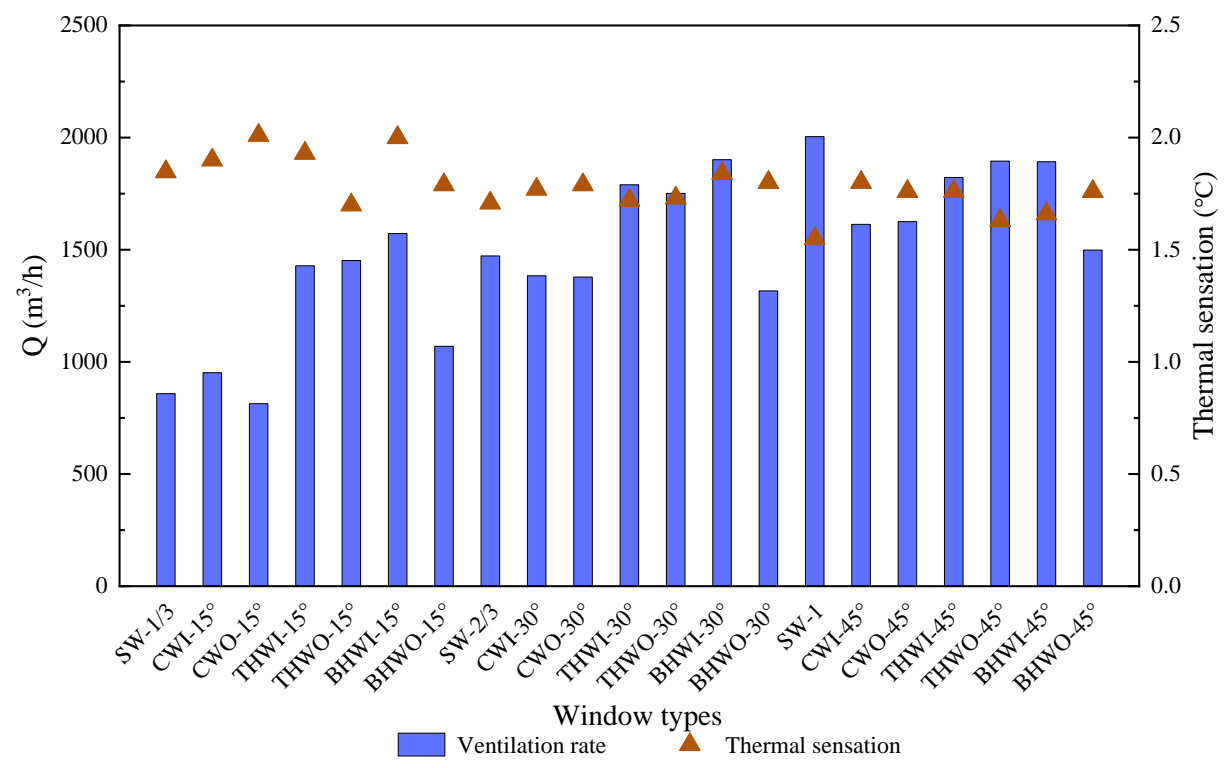

(a)

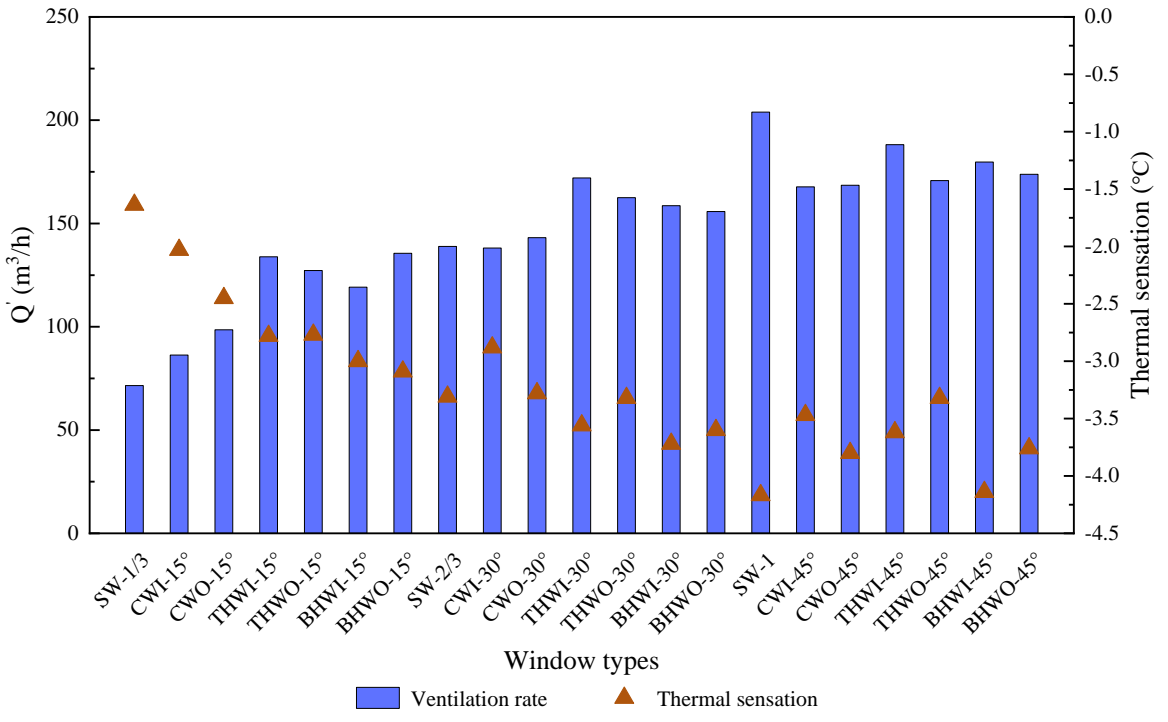

(b)

Figure 11. Comprehensive comparison of ventilation rate and comfort: (a) CV and (b) SV. 
The ratios of the ventilation rate to the absolute value of the thermal sensation for different window types are listed in Table 8 . It can be seen that SW-1 has the best ventilation performance under $\mathrm{CV}$, with a ratio of 1293.26 , and THWI-45 $5^{\circ}$ has the best ventilation performance under SV, with a ratio of 51.97. In summary, THWI and THWO have better ventilation performance under the two ventilation modes.

Table 8. Ratios of the ventilation rate to the absolute value of the thermal sensation for different window-opening forms.

\begin{tabular}{|c|c|c|c|c|c|c|}
\hline \multirow[b]{2}{*}{ Window Types } & \multicolumn{3}{|c|}{$\mathrm{CV}$} & \multicolumn{3}{|c|}{ SV } \\
\hline & $\begin{array}{l}\text { Ventilation } \\
\text { Rate }\left(\mathrm{m}^{3} / \mathrm{h}\right)\end{array}$ & $\begin{array}{c}\text { Thermal } \\
\text { Sensation }\left({ }^{\circ} \mathrm{C}\right)\end{array}$ & Ratio & $\begin{array}{l}\text { Ventilation } \\
\text { Rate }\left(\mathrm{m}^{3} / \mathrm{h}\right)\end{array}$ & $\begin{array}{c}\text { Thermal } \\
\text { Sensation }\left({ }^{\circ} \mathrm{C}\right)\end{array}$ & Ratio \\
\hline SW-1/3 & 858.12 & 1.85 & 464.40 & 71.52 & -1.64 & 43.69 \\
\hline CWI-15 ${ }^{\circ}$ & 952.16 & 1.90 & 501.14 & 86.31 & -2.03 & 42.52 \\
\hline CWO-15 ${ }^{\circ}$ & 814.04 & 2.01 & 405.00 & 98.56 & -2.45 & 40.23 \\
\hline THWI-15 ${ }^{\circ}$ & 1428.25 & 1.93 & 740.03 & 133.86 & -2.78 & 48.15 \\
\hline THWO-15 & 1451.76 & 1.70 & 853.98 & 127.24 & -2.77 & 45.94 \\
\hline BHWI-15 & 1572.25 & 2.00 & 786.13 & 119.14 & -3.00 & 39.71 \\
\hline BHWO-15 & 1069.71 & 1.79 & 597.60 & 135.54 & -3.09 & 43.86 \\
\hline SW-2/3 & 1472.33 & 1.71 & 861.87 & 138.90 & -3.31 & 41.98 \\
\hline CWI-30 & 1384.16 & 1.77 & 782.01 & 138.12 & -2.88 & 47.96 \\
\hline CWO-30 & 1378.29 & 1.79 & 769.99 & 143.16 & -3.28 & 43.65 \\
\hline THWI-30 & 1789.71 & 1.72 & 1040.53 & 172.01 & -3.56 & 48.32 \\
\hline THWO-30 & 1751.51 & 1.73 & 1012.43 & 162.48 & -3.32 & 48.94 \\
\hline BHWI-30 & 1901.39 & 1.84 & 1033.36 & 158.60 & -3.72 & 42.63 \\
\hline BHWO-30 & 1316.57 & 1.80 & 731.43 & 155.81 & -3.60 & 43.28 \\
\hline SW-1 & 2004.25 & 1.55 & 1293.26 & 203.94 & -4.17 & 48.93 \\
\hline CWI-45 & 1613.39 & 1.80 & 896.33 & 167.76 & -3.47 & 48.35 \\
\hline $\mathrm{CWO}-45^{\circ}$ & 1625.14 & 1.76 & 923.38 & 168.51 & -3.80 & 44.34 \\
\hline THWI-45 & 1822.04 & 1.76 & 1035.25 & 188.14 & -3.62 & 51.97 \\
\hline THWO-45 & 1895.51 & 1.63 & 1162.89 & 170.79 & -3.32 & 51.44 \\
\hline $\mathrm{BHWI}-45^{\circ}$ & 1892.57 & 1.66 & 1140.10 & 179.72 & -4.14 & 43.41 \\
\hline $\mathrm{BHWO}-45^{\circ}$ & 1498.78 & 1.76 & 851.58 & 173.79 & -3.76 & 46.22 \\
\hline
\end{tabular}

\section{Conclusions}

In this study, the ventilation characteristics of a typical office room with different window-opening forms under CV and SV were studied. The ratio of the ventilation rate to the absolute value of thermal sensation was used to evaluate the natural ventilation performance. The main conclusions drawn are as follows.

(1) For $\mathrm{CV}$, on the windward side, the maximum value of the wind pressure coefficient of different window types does not appear at $0^{\circ}\left(360^{\circ}\right)$, but under the symmetrical condition of $22.5^{\circ}\left(337.5^{\circ}\right)$; there is a similar situation on the leeward side, where the minimum value of the coefficient appears in the symmetrical conditions of $157.5^{\circ}$ $\left(202.5^{\circ}\right)$.

(2) For CV and SV, the discharge coefficient increases with the increase in window opening, and the full opening of the sliding window has the highest discharge coefficient, which is 0.68 and 0.52 , respectively. For medium and small openings, the discharge coefficient of the bottom-hung window opening inwards is the highest under CV, whereas that of the top-hung window opening inwards is the highest under SV.

(3) Based on the evaluation of the ventilation performance of different window-opening forms, it is concluded that the sliding window with a full opening has the best ventilation performance under CV, with a ratio of 1293.26, whereas the ventilation performance is the best under SV when the opening of the top-hung window opening inwards is $45^{\circ}$, with a ratio of 51.97. In general, the two types of top-hung windows have better ventilation performance under the two ventilation modes. The results of this study are useful for designers when selecting window types and designing windows with opening restrictors for office buildings. 
Author Contributions: Conceptualization, Y.W., Y.Y., T.Y. and Q.B.; methodology, Y.W. and Y.Y.; software, Y.W. and Y.Y.; validation, Q.B.; formal analysis, Y.W., Y.Y., T.Y. and Q.B.; investigation, T.Y.; resources, Q.B.; data curation, Q.B.; writing—original draft preparation, Y.W. and Y.Y.; writingreview and editing, T.Y.; visualization, T.Y.; All authors have read and agreed to the published version of the manuscript.

Funding: This research was founded by the Science and Technology Planning Project of Tianjin (No. 18ZXGDGX00080).

Institutional Review Board Statement: Not applicable.

Informed Consent Statement: Not applicable.

Data Availability Statement: Not applicable.

Acknowledgments: This work was accomplished in the National Engineering Laboratory for Digital Construction and Evaluation Technology of Urban Rail Transit.

Conflicts of Interest: The authors declare no conflict of interest.

\section{Nomenclature}

\begin{tabular}{|c|c|}
\hline BHWI & Bottom-hung window opening inwards \\
\hline BHWI-15 & Bottom-hung window opening inwards at $15^{\circ}$ \\
\hline BHWI-30 & Bottom-hung window opening inwards at $30^{\circ}$ \\
\hline $\mathrm{BHWI}-45^{\circ}$ & Bottom-hung window opening inwards at $45^{\circ}$ \\
\hline BHWO & Bottom-hung window opening outwards \\
\hline BHWI & Bottom-hung window opening inwards \\
\hline BHWI-15 $5^{\circ}$ & Bottom-hung window opening inwards at $15^{\circ}$ \\
\hline BHWI-30 & Bottom-hung window opening inwards at $30^{\circ}$ \\
\hline BHWI-45 & Bottom-hung window opening inwards at $45^{\circ}$ \\
\hline BHWO & Bottom-hung window opening outwards \\
\hline $\mathrm{BHWO}-15^{\circ}$ & Bottom-hung window opening outwards at $15^{\circ}$ \\
\hline $\mathrm{BHWO}-30^{\circ}$ & Bottom-hung window opening outwards at $30^{\circ}$ \\
\hline $\mathrm{BHWO}-45^{\circ}$ & Bottom-hung window opening outwards at $45^{\circ}$ \\
\hline CFD & Computational fluid dynamics \\
\hline $\mathrm{CV}$ & Wind-driven cross-ventilation \\
\hline BHWI & Bottom-hung window opening inwards \\
\hline BHWI-15 $5^{\circ}$ & Bottom-hung window opening inwards at $15^{\circ}$ \\
\hline $\mathrm{BHWI}-30^{\circ}$ & Bottom-hung window opening inwards at $30^{\circ}$ \\
\hline BHWI- $45^{\circ}$ & Bottom-hung window opening inwards at $45^{\circ}$ \\
\hline $\mathrm{CWO}-30^{\circ}$ & Casement window opening outwards at $30^{\circ}$ \\
\hline $\mathrm{CWO}-45^{\circ}$ & Casement window opening outwards at $45^{\circ}$ \\
\hline$Q$ & Ventilation rate for wind-driven cross-ventilation $\left(\mathrm{m}^{3} / \mathrm{s}\right)$ \\
\hline$Q^{\prime}$ & Ventilation rate for temperature-driven single-sided ventilation $\left(\mathrm{m}^{3} / \mathrm{s}\right)$ \\
\hline SV & Temperature-driven single-sided ventilation \\
\hline SW & Sliding window \\
\hline SW-1/3 & Sliding window with $1 / 3$ opening \\
\hline $\mathrm{SW}-2 / 3$ & Sliding window with $2 / 3$ opening \\
\hline SW-1 & Sliding window with full opening \\
\hline$t_{c}$ & Human thermal sensation neutral temperature \\
\hline THWI & Top-hung window opening inwards \\
\hline THWI-15 & Top-hung window opening inwards at $15^{\circ}$ \\
\hline THWI-30 & Top-hung window opening inwards at $30^{\circ}$ \\
\hline THWI- $45^{\circ}$ & Top-hung window opening inwards at $45^{\circ}$ \\
\hline THWO & Top-hung window opening outwards \\
\hline THWO-15 $5^{\circ}$ & Top-hung window opening outwards at $15^{\circ}$ \\
\hline THWO-30 & Top-hung window opening outwards at $30^{\circ}$ \\
\hline THWO-45 & Top-hung window opening outwards at $45^{\circ}$ \\
\hline
\end{tabular}




\section{References}

1. Michael, A.; Demosthenous, D.; Philokyprou, M. Natural Ventilation for Cooling in Mediterranean Climate: A Case Study in Vernacular Architecture of Cyprus. Energy Build. 2017, 144, 333-345. [CrossRef]

2. Yao, R.; Li, B.; Steemers, K.; Short, A. Assessing the natural ventilation cooling potential of office buildings in different climate zones in China. Renew. Energy 2009, 34, 2697-2705. [CrossRef]

3. Moosavi, L.; Zandi, M.; Bidi, M. Experimental study on the cooling performance of solar-assisted natural ventilation in a large building in a warm and humid climate. J. Build. Eng. 2018, 19, 228-241. [CrossRef]

4. Cheng, J.; Qi, D.H.; Katal, A.; Wang, L.Z.; Stathopoulos, T. Evaluating wind-driven natural ventilation potential for early building design. J. Wind Eng. Ind. Aerodyn. 2018, 182, 160-169. [CrossRef]

5. Yu, Y.; Wang, B.; You, S.; Ye, T.; Zheng, W.; Wei, S.; Yang, S.; Wang, Y.; Li, K. The effects of manual airing strategies and architectural factors on the indoor air quality in college classrooms: A case study. Air Qual. Atmos. Health 2021. [CrossRef]

6. Dino, G.; Walter, M.; Günter, B.; Hrvoje, K. Wind-tunnel analysis of natural ventilation in a generic building in sheltered and unsheltered conditions: Impact of Reynolds number and wind direction. J. Wind Eng. Ind. Aerodyn. 2020, $207,1-17$.

7. Oropeza-Perez, I.; Ostergaard, P.A. Energy saving potential of utilizing natural ventilation under warm conditions—A case study of Mexico. Appl. Energy 2014, 130, 20-32. [CrossRef]

8. Tong, Z.; Chen, Y.; Malkawi, A.; Liu, Z.; Freeman, R.B. Energy saving potential of natural ventilation in China: The impact of ambient air pollution. Appl. Energy 2016, 179, 660-668. [CrossRef]

9. Xiaofeng, L. Design and Application of Natural Ventilation in Buildings; China Architecture \& Building Press: Beijing, China, 2018.

10. David, E. Natural Ventilation of Buildings:Theory, Measurement and Design; John Wiley \& Sons, Ltd.: Hoboken, NJ, USA, 2011.

11. Allocca, C.; Chen, Q.; Glicksman, L.R. Design analysis of single-sided natural ventilation. Energy Build. 2003, 35, 785-795. [CrossRef]

12. Abdullah, H.K.; Alibaba, H.Z. Window Design of Naturally Ventilated Offices in the Mediterranean $\mathrm{Climate}$ in Terms of $\mathrm{CO}_{2}$ and Thermal Comfort Performance. Sustainability 2020, 12, 473. [CrossRef]

13. Sacht, H.; Lukiantchuki, M.A. Windows Size and the Performance of Natural Ventilation. Procedia Eng. 2017, 196, 972-979. [CrossRef]

14. Du, L.; Lau, S.-K.; Lee, S.E.; Danzer, M.K. Experimental study on noise reduction and ventilation performances of sound-proofed ventilation window. Build. Environ. 2020, 181, 1-9. [CrossRef]

15. Grabe, J.V.; Svoboda, P.; Baeumler, A. Window ventilation efficiency in the case of buoyancy ventilation. Energy Build. 2014, 72, 203-211. [CrossRef]

16. Liang, W.; Jun, L.; Juan, Z.; Lei, H.; Xi, L.Y. Analysis of the influence of window opening modes on natural ventilation in living room. J. Chongqing Univ. 2011, 34, 75-79.

17. Fan, S.; Davies Wykes, M.S.; Lin, W.E.; Jones, R.L.; Robins, A.G.; Linden, P.F. A full-scale field study for evaluation of simple analytical models of cross ventilation and single-sided ventilation. Build. Environ. 2021, 187, 1-11. [CrossRef]

18. Chen, Z.; Bai, L.; Li, F. Effects of external window form on residential building energy consumption. In Proceedings of the 4th International Conference on Manufacturing Science and Engineering (ICMSE 2013), Dalian, China, 30-31 March 2013; pp. 1619-1624.

19. Barlow, S.; Fiala, D. Occupant comfort in UK offices-How adaptive comfort theories might influence future low energy office refurbishment strategies. Energy Build. 2007, 39, 837-846. [CrossRef]

20. Favarolo, P.A.; Manz, H. Temperature-driven single-sided ventilation through a large rectangular opening. Build. Environ. 2005 40, 689-699. [CrossRef]

21. Heiselberg, P.; Svidt, K.; Nielsen, P.V. Characteristics of airflow from open windows. Build. Environ. 2001, 36, 859-869. [CrossRef]

22. Yang, C.; Shi, H.; Yang, X.; Zhao, B. Research on Flow Resistance Characteristics with Different Window/Door Opening Angles. HVACR Res. 2010, 16, 813-824. [CrossRef]

23. Liu, T.Q.; Lee, W.L. Influence of window opening degree on natural ventilation performance of residential buildings in Hong Kong. Sci. Technol. Built Environ. 2020, 26, 28-41. [CrossRef]

24. Jin, R.Q.; Hang, J.; Liu, S.S.; Wei, J.J.; Liu, Y.; Xie, J.L.; Sandberg, M. Numerical investigation of wind-driven natural ventilation performance in a multi-storey hospital by coupling indoor and outdoor airflow. Indoor Built Environ. 2016, 25, $1226-1247$. [CrossRef]

25. Deng, H.Y.; Feng, Z.B.; Cao, S.J. Influence of air change rates on indoor $\mathrm{CO}_{2}$ stratification in terms of Richardson number and vorticity. Build. Environ. 2018, 129, 74-84. [CrossRef]

26. Buratti, C.; Mariani, R.; Moretti, E. Mean age of air in a naturally ventilated office: Experimental data and simulations. Energy Build. 2011, 43, 2021-2027. [CrossRef]

27. Yang, R.Q.; Zhang, H.; You, S.J.; Zheng, W.D.; Zheng, X.J.; Ye, T.Z. Study on the thermal comfort index of solar radiation conditions in winter. Build. Environ. 2020, 167, 106456. [CrossRef]

28. He, Y.D.; Chen, W.H.; Wang, Z.; Zhang, H. Review of fan-use rates in field studies and their effects on thermal comfort, energy conservation, and human productivity. Energy Build. 2019, 194, 140-162. [CrossRef]

29. de Dear, R.J.; Brager, G.S. Thermal comfort in naturally ventilated buildings: Revisions to ASHRAE Standard 55. Energy Build. 2002, 34, 549-561. [CrossRef]

30. Yu, Z.; Fu, Y.; Chen, M. Research on Thermal Comfort Models for Naturally Ventilated Buildings. Build. Sci. 2017, 33, 176-182. 
31. Su, X.; Zhang, X.; Gao, J. Evaluation method of natural ventilation system based on thermal comfort in China. Energy Build. 2009, 41, 67-70. [CrossRef]

32. General Administration of Quality Supervision, Inspection and Quarantine of the People's Republic of China. GB/T 18883-2002 Indoor Air Quality Standard; China Standards Press: Beijing, China, 2002.

33. Li, Z. Analysis and Research on Resistance Characteristics of Building Windows. Master's Thesis, Chang'an University, Xi'an, China, 2012.

34. Qing, L. Study on the Influence of Door and Window Opening on Indoor Natural Ventilation Environment. Master's Thesis, Chongqing University, Chongqing, China, 2014.

35. Yao, M.; Zhao, B. Measurement of natural ventilation rate of residences in Beijing, China. Procedia Eng. 2017, 205, 3435-3440. [CrossRef]

36. Zhangwu, X.; Qingyuan, Y.; Shiwei, H.; Yagang, Z. Influence of neighbouring tenants' windowing conditions to the room ventilation. Shanxi Archit. 2015, 41, 121-122.

37. Wen, L. Experimental and Simulation Study on Single-Sided Natural Ventilation Caused by Buoyancy. Master's Thesis, Hunan University, Changsha, China, 2008.

38. Fujun, W. Computational Fluid Dynamics Analysis; Tsinghua University Press: Beijing, China, 2004.

39. Tominaga, Y.; Mochida, A.; Yoshie, R.; Kataoka, H.; Nozu, T.; Yoshikawa, M.; Shirasawa, T. AIJ guidelines for practical applications of CFD to pedestrian wind environment around buildings. J. Wind. Eng. Ind. Aerodyn. 2008, 96, 1749-1761. [CrossRef]

40. Meng, F.Q.; He, B.J.; Zhu, J.; Zhao, D.X.; Darko, A.; Zhao, Z.Q. Sensitivity analysis of wind pressure coefficients on CAARC standard tall buildings in CFD simulations. J. Build. Eng. 2018, 16, 146-158. [CrossRef]

41. Montazeri, H.; Blocken, B. CFD simulation of wind-induced pressure coefficients on buildings with and without balconies: Validation and sensitivity analysis. Build. Environ. 2013, 60, 137-149. [CrossRef]

42. Nicol, J.F.; Humphreys, M.A. A stochastic approach to thermal comfort-Occupant behavior and energy use in buildings. Ashrae Trans. 2004, 110, 554-568.

43. ASHRAE. ANSI/Standard 55-2013 Thermal Environment Conditions for Human Occupancy; ASHRAE: Atlanta, GA, USA, 2013. 